\title{
Karyotype, genetic and morphological variability in North China zokor, Myospalax psilurus (Rodentia, Spalacidae, Myospalacinae)
}

\author{
Andrey Yu. Puzachenko*, Marina V. Pavlenko, \\ Vladimir P. Korablev \& Marina V. Tsvirka
}

\begin{abstract}
Both genetic and morphometric methods have been applied for studying of differentiation in North China zokor, Myospalax psilurus, which includes zokors from Russian Far East (Primorsky Krai), North China, Eastern Mongolia and Russian Transbaikalia (Zabaykalsky Krai). There are two subspecies of North China zokor which were described earlier: M. p. psilurus and M. p. epsilanus. The taxonomic statuses of these forms are debated. The diploid number of chromosomes in tested zokors was 64, but there were notable differences in the karyotype structures from Zabaykalsky Krai ('epsilanus': 9-12 M-SM, 10-13 ST, 8-9 A:) and from Primorsky Krai ('psilurus': 9 M-SM, 13-14 ST, 8-9 A). These populations are clearly differed by spectra of blood serum proteins (transferrins): all samples from Primorsky Krai were found to be monomorphic by TF-B, while the samples from Zabaykalsky Krai possessed TF-C only. Marginal populations from Zabaykalsky Krai and Primorsky Krai have significant differences according to RAPD-PCR results of the study. That allows estimating these differences as corresponding to interspecies level. Genetic distance between them is high and it may be compared with the distance between another zokor species, $M$. aspalax and M. armandii (Pavlenko \& Korablev, 2003a; Puzachenko et al., 2009; Tsvirka et al., 2011). A similar pattern of differentiation is detected by sequencing of mitochondrial markers: hypervariable region D-loop and cytochrome $b$ (Tsvirka et al, 2009a).

The main morphological differences within the North China zokor were found out in hard palate features (foramina incisive size and construction, length of maxillary bone). According to the available data, zokors from Primorsky Krai are identical to the zokors from the southern part of the species range and are considered as typical M. p. psilurus. The zokors from the Great Khingan region must be considered as $M$. p. epsilanus. The zokors from Zabaykalsky Krai and Eastern Mongolia are definitely close to M. $p$. epsilanus by the morphometric data, but have some specific features in foramina incisiva construction, the length of the $M_{1}$ and $M_{2}$ and the total length of the upper tooth-row. So, we propose to consider this form as a separate subspecies of the North China zokor provisionally. For the further revision, integrated genetic and morphological research of the zokors from the Chinese part of the species range is necessary to be done.
\end{abstract}

KEY WORDS: Myospalacinae, North China zokor, karyotype, protein markers, RAPD-PCR, multivariate morphometry, skull, China, Primorsky Krai, Zabaykalsky Krai.

Andrey Yu. Puzachenko [puzak1@rambler.ru], Institute of Geography, Russian Academy of Sciences, Staromonetnyi per., 22, Moscow 109017, Russia; Marina V. Pavlenko [pavlenko@ibss.dvo.ru], Institute of Biology and Soil Science, Far Eastern Branch of the Russian Academy of Sciences, 159 Prospect Stoletiya, Vladivostok 690022, Russia; Vladimir P. Korablev (deceased), Institute of Biology and Soil Science, Far Eastern Branch of the Russian Academy of Sciences, 159 Prospect Stoletiya, Vladivostok 690022, Russia; Marina V. Tsvirka [tsvirka@ibss.dvo.ru], Institute of Biology and Soil Science, Far Eastern Branch of the Russian Academy of Sciences, 159 Prospect Stoletiya, Vladivostok 690022, Russia.

\section{Кариотипическое, генетическое и морфологическое разнообразие северокитайского цокора, Myospalax psilurus (Rodentia, Spalacidae, Myospalacinae)}

\author{
А.Ю. Пузаченко, М.В. Павленко, В.П. Кораблев, М.В. Цвирка
}

РЕЗЮМЕ. Генетическими и морфометрическими методами исследовано разнообразие северокитайских ('маньчжурских') цокоров Myospalax psilurus, включающих цокоров российского Дальнего Востока (Приморский край), Северного Китая, Восточной Монголии и Забайкалья (Забайкальский край). Ранее были описаны два подвида северокитайских цокоров M. p. psilurus и M. p. epsilanus, статус которых недостаточно обоснован. Кариотипы всех исследованных северокитайских цокоров содержат 64 хромосомы, но существенно различаются по структуре в популяциях Забайкальского края ('epsilanus': 9-12 M-SM, 10-13 ST, 8-9 А) и Приморского края ('psilurus': 9 M-SM, 13-14 ST, 89 А). Эти же популяции хорошо различаются по спектрам белков плазмы крови (трансферинов): у 
цокоров из Приморского края выделен мономорфный TF-B, а в Забайкальском крае - TF-C. Краевые популяции вида в России четко разделяются по результатам RAPD-PCR анализа. Генетические дистанции между ними сопоставимы с аналогичным дистанциям между видами M. aspalax и M. armandii (Pavlenko \& Korablev, 2003a; Puzachenko et al., 2009; Tsvirka et al., 2011). Исследования митохондриальных маркеров (гипервариабельного региона D-петли и цитохрома $b$ ) подтверждают генетическую дифференциацию изученных популяций (Tsvirka et al., 2009a). Основные морфометрические и морфологические различия внутри северокитайских цокоров обнаружены в области твердого неба (размеры и строение foramina incisive, длина верхнечелюстных костей). По этим признакам животные из Приморского края оказались идентичными с экземплярами из окрестностей Пекина, т.е. типичными M. p. psilurus, и хорошо отличались от цокоров Забайкальского края и Восточной Монголии. Последние оказались ближе к цокорам Северного Китая, включая Большой Хинган (M. p. epsilanus), но отличались от них особенностями строения foramina incisive, по размерам $\mathrm{M}_{1}, \mathrm{M}_{2}$ и длине верхнего зубного ряда. На основании имеющихся данных предлагается предварительно рассматривать этих цокоров в качестве отдельного подвида северокитайского цокора. Дальнейшая таксономическая ревизия группы должна строиться на результатах нового комплексного генетико-морфологического исследования, включающего материал из китайской части видового ареала.

КЛЮЧЕВЫЕ СЛОВА: Myospalacinae, северокитайский цокор, кариотип, белковые маркеры, RAPD$\mathrm{PCR}$, многомерный анализ, череп, Китай, Приморский край, Забайкальский край.

\section{Introduction}

Zokors Myospalacinae Lilljeborg, 1866 constitute a group of rodents specialized for subterranean life style. In general, all the recent and vast majority of fossil zokors are Asian endemics. Molecular-genetic studies (nuclear genes and mitochondrial protein coding genes) within Spalacidae during the last decade suggest that Myospalacinae and Rhizomyinae form a sister group related to Spalacinae (Norris et al., 2004; Jansa \& Weksler, 2004; Jansa et al., 2009; Flynn, 2009; Lin et al., 2014). The subfamily includes one genus with two subgenera, or two genera, combining zokors with different states of the skull: Eospalax G.M. Allen, 1938 convex occipital shield, long incisive foramina bisected by premaxillary-maxillary suture, carotid canal at basioccipital-basisphenoid suture, configuration of pterygoid fossa, hypsodont and rootless molars; Myospalax Laxmann, 1773 - flat occipital shield, short incisive foramina within premaxillary bone, rooted (extinct species) or rootless molars (recent) (Allen, 1938; Fan \& Shi, 1982; Carleton \& Musser, 2005; Smith \& Xie, 2008).

The taxonomy of the recent Myospalacinae includes from 5 to 10 species (Allen, 1909; Ognev, 1947; Li \& Chen, 1987; Lawrence, 1991; Zheng \& Cai, 1991; Zheng, 1994; McKenna \& Bell, 1997; Nowak, 1999; Carleton \& Musser, 2005; Smith \& Xie, 2008).

A recent full-scale revision of the zokors has not been carried out. New evidence including combined results of genetic, and morphometric researches should inevitably lead to the revision of Myospalacinae taxonomy (Pavlenko \& Korablev, 2005; Korablev \& Pavlenko, 2007a, b; Cai et al., 2007; Zhou \& Zhou, 2008; Tsvirka et al., 2011).

The North China zokor, Myospalax psilurus (Milne-Edwards, 1874) was described from Chihli ( $=\mathrm{He}-$ bei), south of Beijing (China). This zokor has a compli- cated upper first molar $\left(\mathrm{M}^{1}\right)$, as in most other recent zokors (Puzachenko et al., 2009) (Fig. 1). The terra typica of M. epsilanus (Thomas, 1912) is the Greater Khingan Range (North-East China). The validity of this species has been debated for about one century. This form is usually interpreted as a synonym of M. psilurus (Carleton \& Musser, 2005). Ognev (1947) believed that 'epsilanus' is the valid subspecies of North China zokor only, which is distributed throughout East Transbaikalia (Zabaykalsky Krai, Russia), Greater Khingan region, Manchuria (China) and southern Far East (Russia). This interpretation of the North China zokor (with two subspecies, M. psilurus psilurus and M. psilurus epsilanus) became dominant in Russia and China (Pavlinov \& Rossolimo, 1987; Zheng, 1994; Gromov \& Erbaeva, 1995; Zhang et al., 1997). Meanwhile, several reviews and original publications considered M. epsilanus a separate zokor species along with M. psilurus (Lawrence, 1991; Pavlinov \& Rossolimo, 1998). Lawrence (1991) basing on the small amount of material considered that M. epsilanus has some very primitive
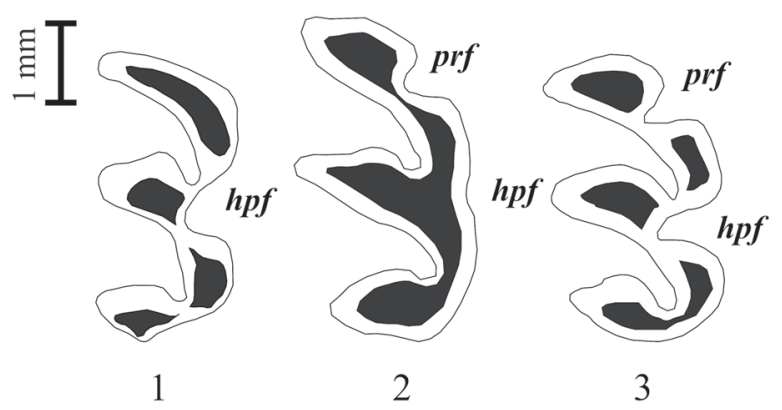

Figure 1. The main variants of $\mathrm{M}^{1}$ (right) in recent Myospalacinae: 1 - 'simple': M. aspalax and M. armandii; 2 'complex I': M. myospalax; 3 - 'complex II': all other zokors. prf - protoflecsus, hpf - hypoflexus. 


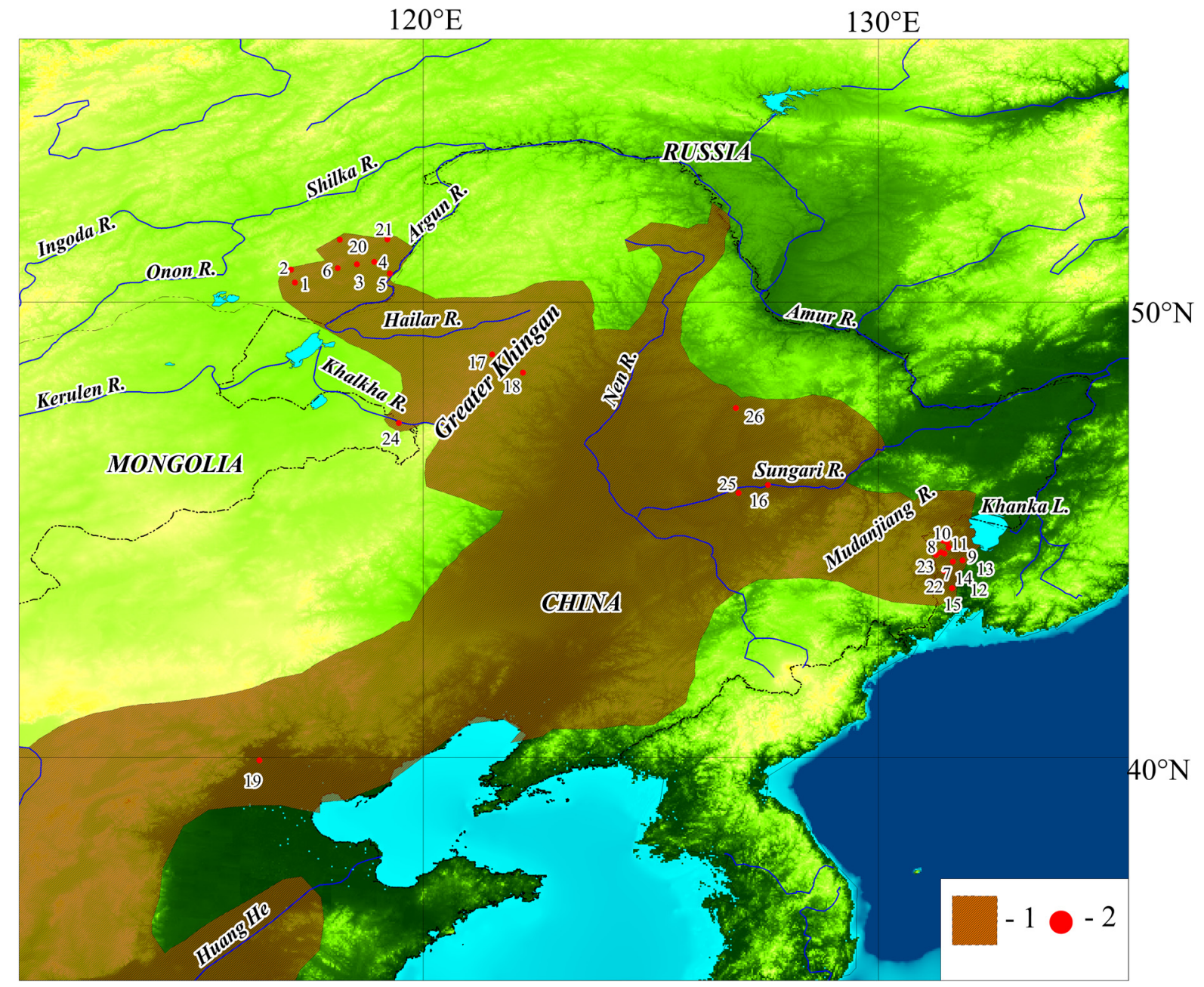

Figure 2. Supposed range of the 'psilurus - epsilanus' zokors (1) and the geographical localities of the specimens used in this study (2). Russia (Zabaykalsky Krai, Primorsky Krai): 1 - Tsagan-Olui Village; 2 - Ust'-Ozernaya Village; 3 - Dono Village (around Kalga); 4 - Kalgukan River valley; 5 - Zargol Village; 6 - Butuntaj Village; 7 - Bojkoe Village; 8 Pad' Karantinnaja (dale); 9 - Pad' Gladkaya (dale); 10 - Barabash-Levada Village and Reshetnikovo (former) Village; 11 Duhovskoe Village; 12 - Druzhba Village; 13 - Priluki Village; 14 - Il'ichevka Village; 15 - Krounovka Village; 20 Gazimurskie Kavykuchi Village; 21 - Bol'shoj Zerentuj Village; 22 - Talovka River valley; 23 — Grodekovo Village. Mongolia: 24 - Numurgin Gol River valley. China: 16 - Hsiaoling station; 17 - Gorigol station; 18 - Yalu station; 19 suburbs of Beijing; 25 - suburbs of Harbin, Sungari River valley; 26 - High Bay station.

features in the base of skull, which brings it together with M. psilurus to Pleistocene and even Pliocene zokors. Carleton \& Musser (2005) noted that the characters (palatal holes) used by Lawrence (1991) are qualitative in nature and may reflect individual or geographic variation. As a result, they joined to Ognev's opinion (Ognev, 1947). The hypothesis about relative genetic independence of the zokors from Russian Far East and Transbaikalian region has been discussed as well (Pavlenko \& Korablev, 2003a). This hypothesis bases on the cytogenetic and genetic data (Martynova, 1975, 1976, 1978; Martynova et al., 1977; Korablev et al., 2009; Korablev \& Pavlenko, 2007a; Pavlenko \& Korablev, 1999, 2003a, 2005; Pavlenko et al., 2008; Zhou \& Zhou, 2008; Tsvirka et al., 2009a, b, 2011).
Cytogenetic and genetic status of the zokors from North China is unclear until now.

In this paper, we denote North China M. psilurus as 'psilurus - epsilanus' group. The range of these zokors (Fig. 2) occupies North-East and North China and a part of Inner Mongolia Autonomous Region. Only the peripheries of this range extend into Russia: Transbaikalia (Zabaykalsky Krai), and Far East (Primorsky Krai). Another small part of the range we found on the extreme east of Mongolia.

In the past few years, new genetic and morphological materials were obtained from the Russian part of the range. This allowed us to fulfill the multidisciplinary research of variability within 'psilurus - epsilanus' group. It should be emphasized that the zokor' popula- 
Table 2. The locations of the main cytogenetic/genetic and morphologic materials used in the study of the North China zokor ('psilurus -epsilanus' group)

\begin{tabular}{|c|c|c|c|c|c|c|}
\hline \multirow[t]{2}{*}{ No } & \multicolumn{3}{|c|}{ Geographical location } & \multicolumn{3}{|c|}{ Number of specimens } \\
\hline & \multicolumn{3}{|c|}{ Cytogenetic/genetic material } & EP & $\mathrm{CG}$ & $\mathrm{M}$ \\
\hline 1 & $\begin{array}{l}\text { Zabaykalsky Krai, } \\
\text { Russia }\end{array}$ & Borzinsky District & near Tsagan-Olui Village & $14^{*}$ & 4 & 6 \\
\hline 2 & ibid & ibid & near Ust'-Ozernaya Village & 3 & 3 & 3 \\
\hline 3 & ibid & Kalgansky District & $\begin{array}{l}\text { near Dono Village and Kalga } \\
\text { Village }\end{array}$ & 4 & 1 & 4 \\
\hline 4 & ibid & Priargunsky District & Kalgukan River valley & 2 & & 1 \\
\hline 5 & ibid & the same place & near Zargol Village & 2 & & 2 \\
\hline 6 & ibid & $\begin{array}{l}\text { Aleksandrovo-Zavodsky } \\
\text { District }\end{array}$ & near Butuntai Village & 1 & & 1 \\
\hline 7 & $\begin{array}{l}\text { Primorsky krai, } \\
\text { Russia }\end{array}$ & Pogranichny District & near Boikoye Village & 6 & & 6 \\
\hline 8 & ibid & ibid & Pad' Karantinnaja (dale) & 6 & 6 & \\
\hline 9 & ibid & ibid & Pad' Gladkaya (dale) & $12 *$ & 6 & 4 \\
\hline 10 & ibid & ibid & $\begin{array}{l}\text { near Barabash-Levada Village } \\
\text { and Reshetnikovo (former) } \\
\text { Village }\end{array}$ & $11^{*}$ & 7 & 4 \\
\hline 11 & ibid & ibid & near Duhovskoye Village & 1 & & \\
\hline 12 & ibid & ibid & near Druzhba Village & 1 & & \\
\hline 13 & ibid & Khorol'skii District & near Priluki Village & $10^{*}$ & & 4 \\
\hline 14 & ibid & Oktjabr'skii District & near Il'ichevka Village & 7 & & 4 \\
\hline \multirow[t]{2}{*}{15} & ibid & Ussuriyskii District & near Krounovka Village & $18^{*}$ & & 5 \\
\hline & \multicolumn{3}{|c|}{ Morphologic material } & M & $\bar{F}$ & \\
\hline 1 & China & Heilongjiang province & near Harbin (Hsiaoling station) & 7 & 4 & \\
\hline 2 & ibid & $\begin{array}{l}\text { Nei Mongol Zizhiqu (Inner } \\
\text { Mongolia) Autonomous Region }\end{array}$ & Gorigol station & & 1 & \\
\hline 3 & ibid & ibid & Yalu station & 1 & 1 & \\
\hline 4 & ibid & Beijing Municipality & suburbs of Beijing & & 1 & \\
\hline \multirow[t]{2}{*}{5} & $\begin{array}{l}\text { Zabaykalsky Krai, } \\
\text { Russia }\end{array}$ & Borzinsky District & near Tsagan-Olui Village & 4 & 2 & \\
\hline & ibid & ibid & & 1 & & \\
\hline 6 & ibid & ibid & near Ust'-Ozernaya Village & 2 & & \\
\hline 7 & ibid & $\begin{array}{l}\text { Aleksandrovo-Zavodsky } \\
\text { District }\end{array}$ & near Butuntai Village & 1 & & \\
\hline 8 & ibid & Gazimuro-Zavodskii District & $\begin{array}{l}\text { near Gazimurskie Kavykuchi } \\
\text { Village }\end{array}$ & & 1 & \\
\hline 9 & ibid & Nerchinsko-Zavodsky District & near Bol'shoi Zerentui Village & & 2 & \\
\hline 10 & $\begin{array}{l}\text { Primorsky Krai, } \\
\text { Russia }\end{array}$ & Pogranichnyi District & near Bojkoe Village & 5 & 4 & \\
\hline 11 & ibid & ibid & near Grodekovo Village & 1 & & \\
\hline 12 & ibid & ibid & Pad' Karantinnaya (dale) & 1 & & \\
\hline 13 & ibid & ibid & Pad' Gladkaya (dale) & 1 & 2 & \\
\hline 14 & ibid & ibid & $\begin{array}{l}\text { near Barabash-Levada Village } \\
\text { and Reshetnikovo (former) } \\
\text { Village }\end{array}$ & & 2 & \\
\hline 15 & ibid & ibid & near Duhovskoye Village & & 1 & \\
\hline 16 & ibid & Khorolsky District & near Priluki Village & 1 & 1 & \\
\hline 17 & ibid & Oktyabrsky District & near Il'ichevka Village & 3 & 4 & \\
\hline 18 & ibid & ibid & Talovka River valley & 2 & & \\
\hline 19 & ibid & Ussuryisky District & near Krounovka Village & 6 & 1 & \\
\hline \multirow[t]{3}{*}{20} & ibid & Khankaysky District & ibid & & 1 & \\
\hline & ibid & ibid & ibid & & 1 & \\
\hline & \multicolumn{6}{|c|}{ Additional morphologic materials: defective skulls of adult, immature specimens } \\
\hline 1 & Mongolia & Eastern District (Aimag) & Numurgin Gol River valley & & & \\
\hline 2 & China & $\begin{array}{l}\text { Heilongjiang (Heilogiang) } \\
\text { Province }\end{array}$ & suburbs of Sungari River valley & & & \\
\hline 3 & ibid & ibid & High Bay station & & & \\
\hline
\end{tabular}

Comments: M — data for RAPD-PCR analysis; EP — data for electrophoretic analysis of protein; CG — data for cytogenetic analysis. * — several samples for some years. 
tion from Primorsky Krai is included in the Red Data Book of Russia. Therefore, the study of their status has both theoretical and applied meanings (Kostenko, 1970, 1989; Korablev \& Pavlenko, 2004; Pavlenko \& Korablev, 1999, 2003a, b; Kostenko \& Korablev, 2005; Chelomina et al., 2003, 2011).

\section{Material and methods}

Cytogenetic studies. Karyotypes of 27 zokor specimens from 7 localities: 8 from Transbaikalia and 19 from Russian Far East were studied (Fig. 2, Tab. 1). Chromosome preparations were made by standard methods (Ford \& Hamerton, 1956) — a method of stimulation of cell division in the red bone marrow with a solution of baker's yeast was used (Lee \& Elder, 1980).

The studies of the blood serum proteins electrophoretic activity. Samples of blood serum from 133 individuals of zokors were used as the material for the study. Ninety-eight specimens from Transbaikalia and Far East of Russia were investigated. Samples from $M$. aspalax (Pallas, 1776) $(n=10)$ and M. armandii (MilneEdwards, 1867) $(n=17)$ from Transbaikalian region, as well as Siberian zokor M. myospalax (Laxmann, 1773) $(n=8)$ from Altai region were used for the comparison (Tab. 1).

Starch gel electrophoresis of the proteins was performed in accordance with generally accepted methods (Pasteur et al., 1988). Electrophoretic conditions obtained the highest quality of electrophoretic spectra of this protein (transferrins) in mammals (Fomicheva, 1973). Modification of this method was applied previously (Martynova et al., 1977) for analysis of three species of zokors, that allows us to compare our results with the descriptions and photos of transferrins spectra, which were made by previous authors. We should emphasize that the samples from Tsagan-Olui (Zabaykalsky Krai) and Boikoye (Primorsky Krai) settlements originated from the same places that had been investigated earlier (Martynova et al., 1977).

Random amplification of polymorphic DNA PCR (RAPD-PCR). We obtained tissue samples from 45 specimens of $M$. psilurus from 12 localities, as well as from three species $M$. aspalax $(n=16), M$. armandii $(n=20)$, M. myospalax $(n=7)$. Mole rat, Spalax microphthalmus Güldenstädt, $1770(n=2)$ was also used as an outgroup. Genomic DNA was extracted from fresh or fixed in ethanol tissues by standard phenol/ proteinase K/sodium dodecyl sulfate method (Sambrook et al., 1989).

To detect highly polymorphic amplification products, preliminary testing of 32 decamer oligonucleotide random primers (Sintol, Russia) was carried out. Electrophoregrams of good quality were obtained with nine of the primers (OPA-16, OPC-02, OPC-05, OPC-08, OPC-09, OPC-12, OPC-16, OPC-20, OPD-05). Polymerase chain reaction (RAPD-PCR) was conducted in a Biorad (USA) thermal cycler, using the temperature protocol described earlier (Tsvirka et al., 2011). The reaction mixture contained $15 \mathrm{ng}$ of total DNA, $10 \times$ buffer $(500 \mu \mathrm{M} \mathrm{KCl}, 150 \mathrm{mM}$ Tris_HCl, $\mathrm{pH} 8.8,0.5 \%$ glycerol, $0.1 \%$ Tween-20), $0.2 \mathrm{ml}$ of each dNTP, $0.5 \mu \mathrm{l}$ of the primer, $1.5 \mathrm{ml}$ of Taq polymerase (Sintol, Russia). The RAPD-PCR products were fractionated by electrophoresis in $2 \%$ starch gel containing $0.5 \mathrm{~m} / \mathrm{ml}$ ethidium bromide in $1 \times$ TBE buffer and photographed in UV light. As a molecular weight marker, we used DNA marker M-26 ('Sibenzim', Russia); as negative control we used a probe containing complete amplification mixture without DNA.

RAPD analysis included construction of binary matrices based on the band presence (1) - absence (0), considering all visually detected bands. The data were processed using software TFPGA ver. 1.3 (Miller, 1997) and POPGENE ver. 1.31 (Yeh \& Boyle, 1997), designed or adapted for dominant markers. Trees were constructed using TREECON (Van de Peer \& De Wacher, 1994): genetic similarity trees were constructed by means of unweighted pair-group method with arithmetic average UPGMA and phylogenetic reconstructions, by means of neighbor joining method NJ with bootstrap support of branching significance (Saitou \& Nei, 1987).

Genetic variation of the populations was measured by using average (na) and effective (ne) numbers of alleles per locus, gene diversity $h$, and the proportion of polymorphic loci $P$ (Yeh \& Boyle, 1997). To estimate genetic differences among the samples and the degree of their isolation, we used total genetic diversity Dst, calculated on the basis of the total intrasample genetic diversity $H t$ and mean sample genetic diversity $H s$, coefficients of genetic differentiation Gst, genetic distances $D$, and genetic similarity $S$, and performed exact test for population differentiation (Miller, 1997; Yeh \& Boyle, 1997).

Morphology and morphometric. Morphometric study was based on 89 skulls of adult zokors (53 females and 36 males) from 23 localities across Russia and China (Fig. 2, Tab. 1). The age was defined by occipital shield and lambdoidal/sagittal crests development (Ognev, 1947; Galkina \& Nadeev, 1980). Sixtyone measurements were taken on each skull by using sliding calipers 'Enkor' (Marking 9530) (see Fig. 3). The additional material includes 22 defective skulls of the adult and immature specimens from China and Mongolia. In addition, we used the data on False zokor (M. aspalax), Armand's zokor (M. armandii) and Siberian zokor (M. myospalax) (Puzachenko et al., 2009).

We examined the collections of the Zoological Institute of the Russian Academy of Sciences (Saint Petersburg, Russia: ZIN), the Zoological Museum of Moscow State University (Moscow, Russia: ZMMU) and the collections of the Institute of Biology and Soil Science of the Far Eastern Branch of the Russian Academy of Sciences (Vladivostok, Russia: IBSS).

The main goals of our study were to describe the main pattern of the skull variability within the 'psilurus -epsilanus' group, and to test the 'null hypothesis' on 
homogeneity of the samples. The sequence of morphomethric analyses was described in detail (Puzachenko, 2006; Abramov et al., 2009; Baryshnikov \& Puzachenko, 2011). All measurements were standardized to exclude any influence of the 'scale' of measurements on the results. The square dissimilarity matrix with Euclidean distances and the matrix of Kendall's tau-b rank order coefficients (Sneath \& Sokal, 1973) among all the pairs of specimens were calculated.

The dissimilarity matrices were used in the nonmetric multidimensional scaling (MDS) procedure (Kruskal, 1964; Davison \& Jones, 1983), which visualizes proximity of relations of objects by distances between points in a low-dimensional Euclidean space. The MDS produces non-correlated dimensions (MDS axes) that hold the main information on the variation of the measurements of skulls. The 'best-minimum' dimension in MDS model was estimated having been based on 'Kruskal's stress' according to the method described previously (Puzachenko, 2001; Kupriyanova et al., 2003; Abramov \& Puzachenko, 2005; Abramov et al., 2009). The method assumes that if the distribution of the dissimilarities in the input matrix is close to random (normal distribution or rectangular), the value of the stress function must be maximal, and the Kruskal's stress monotonically and smoothly decreases according to an increase in the number of dimensions (from 1 to 15 in our case). Under equal circumstances for real nonrandom data, the best MDS solution must be associated with a minimum Kruskal's stress value that deviates relatively maximally from the model value. In general, we assumed the linear regression model. Furthermore, after plotting the standardized residuals vs. dimensions from this regression model, the minimum value and corresponding 'best' dimensionality can be easily found.

The MDS axes for a model based on the Euclidean distances matrix are marked as E1, E2 ... and MDS axes based on Kendall's rank correlation matrix are marked as $\mathrm{K} 1, \mathrm{~K} 2$...

Biological interpretation of the MDS axes based on the results of correlation and multiple regression analyses. We used Spearman rank correlation coefficient between the skull measurements and MDS axes. Multiple regression models were built for every measurement where MDS axes were independent variables. Square of the multiple correlation coefficient in each model is estimation of explained variance of the measurement by MDS axes.

Variance component analysis (Searle et al., 1992) is used for testing both null hypotheses of homogeneity of MDS axes variation in geographical space and absence of sexual dimorphism effect.

Hierarchic classifications (UPGMA with Euclidean distance metric) of all samples were produced having been based on the MDS axes, which were included in modeling multidimensional morphological space and contained almost full information about ordered variability, according to the method of their extraction.
Then, geographical locations of the main morphometrical clusters were investigated. All main results of morphometric analysis were compared with the results of the independent karyotype and genetic studies.

\section{Results}

Cytogenetic and genetic variation. The karyotype of the zokors from 'psilurus-epsilanus' group includes diploid chromosome number of $2 n=64$. There is intrapopulation variability on the chromosome morphology and structure of the karyotypes. These results correspond well to the previous studies of karyotype in zokors (Martynova, 1976). The karyotypes from Primorsky Krai include 9 pairs of meta-submetacentric (M-SM), 13-4 pairs of subtelocentric (ST) and 8-9 pairs of acrocentric (A) autosomes in the karyotype (Fig. 4); one of the largest pairs of autosomes has variation in morphology (ST-A: A/A, A/ST, ST/ST). The ratios of individuals with different karyotype variants varied in the local population samples. For example, there were two individuals with homozygous variant $\mathrm{A} / \mathrm{A}$ and five heterozygous ones with $\mathrm{A} / \mathrm{ST}$ near Barabash-Levada Village, two (A/A and ST/ST) homozygotes and two homozygotes, A/ST found neighborhood of Pad' Gladkaya Village; five heterozygous zokors with $\mathrm{A} / \mathrm{A}$ and one with $\mathrm{A} / \mathrm{ST}$ were captured in the Pad' Karantinnaya locality. During the early studies (Martynova, 1976), three chromosomal variations had been described from the local population near Boykoe Village. Therefore, the high karyotype variability is a specific character of the zokors dwell in the Russian Far East. Against this background, the zokors from $\mathrm{Za}$ baykalsky Krai have relatively low karyotype variability within local populations. Their karyotypes include 9-12 pairs of M/SM autosomes, 10-13 pairs of ST and 8-9 pairs of A autosomes. Only one specimen captured near Dono Village showed the variation in large pair of autosomes morphology, in contrast to the zokors from Primorsky Krai. In other localities (neighborhood of Tsagan-Olui Village, Borzinskii District) previously studied by L.Ya. Martynova (1976), we found homozygotes (ST/ST) only. In conclusion, it should be noted that we did not find the secondary constriction in the $\mathrm{Y}$ chromosome/metacentric autosomes (Martynova, 1976), which was mentioned as specific feature of zokors from Transbaikalia, in contrast to zokor of Primorsky Krai. Therefore, the problem of the differences between populations from Zabaykalsky Krai and Primorsky Krai on this character is still open.

Electrophoretic spectra of transferrins. The revealed pattern of transferrin spectra corresponds to a certain description of the previous study (Martynova et al., 1977). Symbols proposed by L.Ya. Martynova for electrophoretic variants of transferrins were used. Five transferrin variants (phenotypes) were revealed. Each of these variants is a specific monomorphic marker to a particular taxon or geographical population (Fig. 5). Faster variant with the highest electrophoretic mobility 
Table 2. RAPD-marker fragments for the group 'psilurus - epsilanus' zokors

\begin{tabular}{|l|c|c|c|c|c|}
\hline \multirow{2}{*}{ Primers } & \multicolumn{2}{|c|}{ 'psilurus - epsilanus' } & Myospalax & M. spalax & M. armandii \\
\cline { 2 - 4 } & $\begin{array}{c}\text { Transbaikalia } \\
\text { (Russia) }\end{array}$ & $\begin{array}{c}\text { Russian Far } \\
\text { East }\end{array}$ & & & \\
\hline OPA-16 & 610 & 370,270 & $240,340,560$ & 370 & 360 \\
\hline OPC-02 & 580,490 & 510,480 & 420 & 80 & 360 \\
\hline OPC-05 & - & - & - & - & - \\
\hline OPC-08 & - & 460 & $1200,590,550,450$ & - & - \\
\hline OPC-09 & \multicolumn{2}{|c|}{550} & 1500 & - & - \\
\hline OPC-12 & \multicolumn{2}{|c|}{450} & 700,500 & - & - \\
\hline OPC-16 & \multicolumn{2}{|c|}{550} & 240 & - & - \\
\hline OPC-20 & 1200 & - & 700 & - & - \\
\hline OPD-05 & \multicolumn{2}{|c|}{1100,490} & - & 510 & 950,910 \\
\hline
\end{tabular}

is fixed in M. aspalax. In the group 'psilurus-epsilanus' all animals studied from Primorsky Krai, turned out to be monomorphic by TF-B, while zokors from Transbaikalia possessed TF-C. Siberian zokor M. myospalax had the variant with the slowest rate of migration in the gel. Moreover, for the first time, a new variant TF-C1 was revealed for $M$. armandii.

RAPD-PCR analysis. For all the zokors included in the study 463 characters were identified and 152 of these were detected for the group 'psilurus-epsilanus'. The number of amplified fragments in the species varied from 25 to 73 , and in the 'psilurus-epsilanus' group, from 4 to 31 . The molecular weight of the fragments ranged from 100 to $1900 \mathrm{bp}$ (base pairs).

In general, a similar spectrum of amplification of products in the group 'psilurus-epsilanus' was found out. The low population polymorphism in the distribution of the fragments between individuals from the marginal zokor populations was marked. RAPD-spectra obtained with four primers (OPA-16, OPC-02, OPC08, OPC-20) were the most variable. Three informative types of molecular markers were identified: monomorphic, polymorphic and unique. The first type is found only in 'psilurus-epsilanus' group and differs from all other zokor species (OPC-09 ${ }_{550}$, OPC- $12_{450}$, OPC-16 ${ }_{550}$, OPD- $05_{1100}, 490$ ). The second type of primer discriminates individuals among different North China zokor populations (Tab. 2). The third type characterizes some specific taxa or geographical populations of zokor. Thus, for example, OPA-16 $6_{610}$, OPC- $02_{490,580}$ and OPC$20_{1200}$ occur in Transbaikalian populations only; and OPA- $16_{270},{ }_{370}$, OPC-02 ${ }_{480,510}$, OPA-08 ${ }_{460}$ occur in populations from Russian Far East (Khanka Plain). Qualitative differences in the brightness of the fragments between individuals, geographic populations and species of zokors were also revealed.

The level of genetic variability in the combined samples from the marginal populations of "psilurusepsilanus' seems to be similar. The mean $\left(n_{\dot{p}}\right)$ and the effective $(n)$ numbers of alleles per locus in the studied samples of North China zokor were from 1.27 to 1.58. The level of gene diversity $(h)$ for samples from Transbaikalia and Primorye were 0.172 and 0.165 , while the proportion of polymorphic loci (P) was 57.7 and 57.9, respectively. Estimates of $n$ and $h$ highly and positively correlate with each other (correlation coefficient 0.98 ).

The genetic differences between geographically distant samples of 'psilurus-epsilanus' from Transbaikalian region and Russian Far East are not high. The total genetic diversity $\left(D_{\text {st }}\right)$ was 0.03 , the value of gene fixation $\left(G_{s t}\right)$ and genetic distances $(D)$ are 0.16 and 0.08 , respectively. Exact test for differentiation distinguished them as independent forms with high reliability $(\div 2=$ 2309 , df $=926, p<0.01)$. The level of the observed differences between 'psilurus' and 'epsilanus' corresponds to differences between $M$. aspalax - M. armandii, which are considered as separate species (Puzachenko et al., 2009, 2011; Tsvirka et al., 2011).

The zokors from Zabaykalsky Krai and Primorsky Krai form independent groups according to their geographic distribution in the genetic similarity UPGMAdendrogram as well as in NJ-and MST-phylogenetic reconstructions (Fig. 6).

Morphometric studies. The variability of skull size was well described by three MDS axes ('optimal' dimensionality of the morphological space). According to correlation analysis result, the first MDS axis (E1) reproduces the general size variation of the skull (Tab. 3 ). The second axis (E2) describes the general sizeindependent variation in molars, tooth-rows, length of the condyle. The third MDS axis (E3) is correlated with two measurements only: foramen incisivum length and palatal width between labial edges of alveolus of the $\mathrm{M}^{1}$.

The variation of several measurements (width of the $\mathrm{M}^{3}$, interorbital width, length of lower diastem, width of foramen magnum, and some others) is mainly stochastic with normal distribution in most cases by the Kolmogorov-Smirnov test. Among these measurements, only interorbital width has low variance and strongly shrunk non-normal distribution.

The result of variance components analysis showed the contributions of two factors to the variance of MDS axes: the geographical location of subsamples (Primorsky Krai and Zabaykalsky Krai) and sex (Fig. 7). The variance of the first (main) MDS axis (E1) reflects mainly individual variability in size, including sexual dimorphism, and it does not depend on the geographical factor. More than $50 \%$ of the variance of the second 

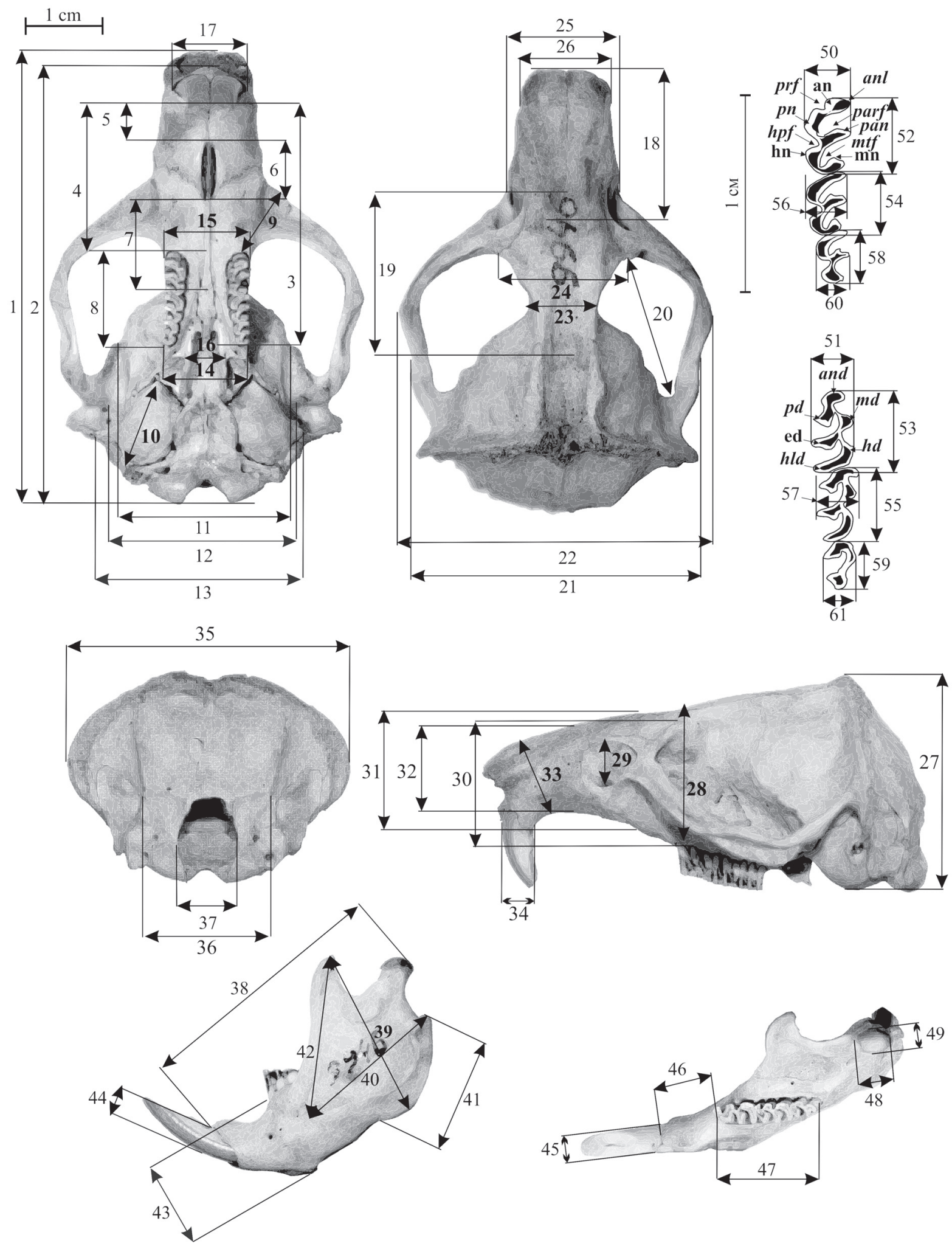


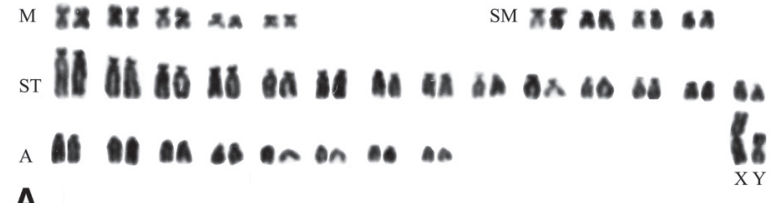

A

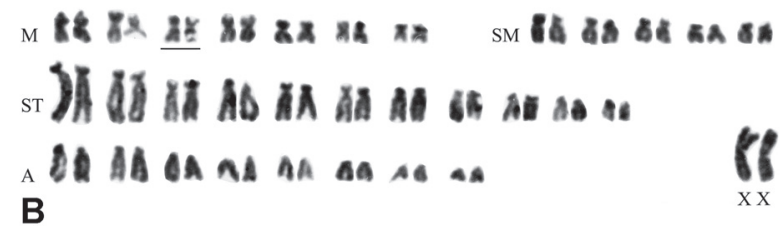

Figure 4. Karyotypes of North China zokors from the 'psilurus - epsilanus' group: A - M. p. psilurus (Primorsky Krai), B - M. p. epsilanus (Zabaykalsky Krai). M - methacentric, SM - submethacentric, ST - subtelocentric, A acrocentric chromosomes. Pair of autosomes with secondary constriction is underlined.

MDS axis (E2) and about $70 \%$ of the variance of the third MDS axis (E3) are connected with the geographical location of subsamples. So, the major part of morphometric information, being of potential interest for the study, is contained in the E2, E3, K1-K3 MDS axes.

The morphospace representing shape variability had three dimensions too. For the first MDS axis (K1), the main factor is the difference in the geographical locations together with noticeable effect of sexual size dimorphism. Thus, the results of the test of 'null hypotheses' on the homogeneity of the 'psilurus-epsilanus' group suggests that the zokors from Zabaykalsky Krai and Primorsky Krai may belong to different statistical samples. These samples differ on the molars, the base of the skull, foramen incisivum, maxillary length (from foramen incisivum), width between anterior edges of glenoid fossae (glenoid cavity), width of $\mathrm{M}_{1}$, length of condyle etc. (Tab. 4). Formally, we can statistically distinguish 'psilurus' and 'epsilanus' by sixteen measurements. However, in practice only length of foramen

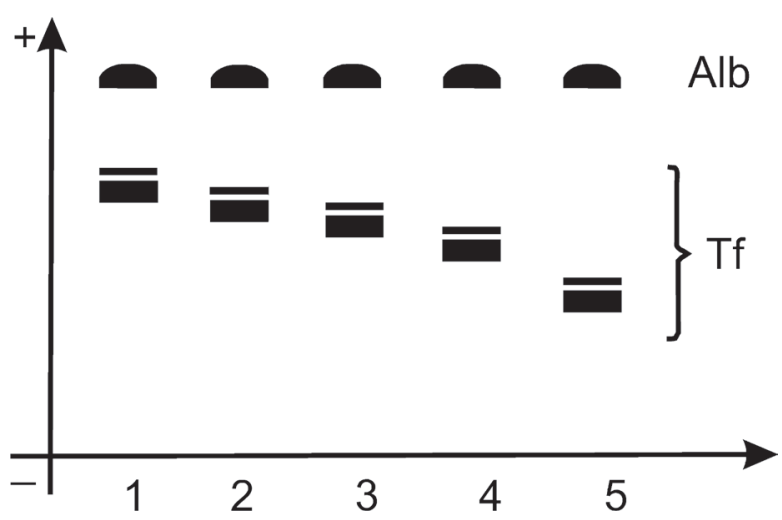

Figure 5. Electrophoretic variants of transferrins in zokors: 1 - Tf-A (M. aspalax, Zabaykalsky Krai); 2 - Tf-B ('psilurus - epsilanus', Primorsky Krai); 3 - Tf-C ('psilurus epsilanus' Zabaykalsky Krai); 4 - Tf-C1 (M. armandii, Zabaykalsky Krai); 5 - Tf-D (M. myospalax, Republic of Altai).

incisivum and maxillary length from foramen incisivum along the sutura intermaxillaris demonstrates relatively sustainable statistical differences between them.

We deliberately did not include in previous variance components analysis the zokors from the China territory. Among them, a specimen from Beijing region (ZMMU S-165144, female) should belong to $M$. $p$. psilurus, and several skulls from the Greater Khingan Range - to M. p. epsilanus. On Fig. 8 in the space of E3 and K1 MDS axes, the skull from Beijing region is situated within the space occupied by zokors from Primorsky Krai, while the specimens from North-East China are placed in the region occupied by zokors from Zabaykalsky Krai.

This result coincides with the result of UPGMA classification of our sample (Fig. 9B: E2, E3, K1-K3 MDS axes - variables; metric — Euclidean distance). Both 'psilurus' and 'epsilanus' forms are completely different on this dendrogram. All Chinese samples, except for the specimen from the suburbs of Beijing,

Figure 3. Scheme of measurements taken of the zokor' skull and molars: 1 - maximal length; 2 - condylobasal length; 3 palatal length; 4 - length of upper diastem; 5 - premaxillare length; 6 - length of foramen incisivum; 7 — maxillary length (from foramen incisivum); 8 - length of upper tooth-row; 9 - length of zygomatic plate; 10 - length of auditory bulla; 11 , 12 - width between anterior and caudal edges of glenoid fossae (glenoid cavity); 13 - mastoid width; 14, 15 — palatal width between external edges of alveolus of $\mathrm{M}^{1}, \mathrm{M}^{3} ; 16$ - width between left and right pterygoid processus; 17 — double upper incisive width; 18 - length of nasal bone; 19 - length of frontal bone; 20 - length of orbit; 21,22 — zygomatic width and maximal zygomatic width; 23 - interorbital width; 24 - width of frontal bones, 25 - maximal width of rostrum; 26 minimal width of rostrum; 27 - cranial height; 28 - cranial height at anterior edge of upper tooth row level; 29 - height of infraorbital foramen; 30 - height of zygomatic arch; 31 - maximal height of rostrum; 32 - middle height of rostrum; 33 minimal height of rostrum; 34 - breadth of upper incisive; 35, 36 - maximal and 'minimal' breadth of occipital shield; 37 width of foramen magnum; 38 - length of mandible; 39 - height between angular process and apex of coronoid process; 40 - length between anterior corner of masseteric fossa and apex of angular process; 41 - length of angular process; 42 length of coronoid process; 43 - height of horizontal branch of mandible; 44, 45 - thickness and width of lower incisor; 46 length of lower diastem; 47 - length of lower tooth-row; 48, 49 - length and width of condyle; 50, 51 — length of $\mathrm{M}^{1}$ and $\mathrm{M}_{1} ; 52,53$ - width of $\mathrm{M}^{1}$ and $\mathrm{M}_{1} ; 54,55$ - length of $\mathrm{M}^{2}$ and $\mathrm{M}_{2} ; 56,57$ - width of $\mathrm{M}^{2}$ and $\mathrm{M}_{2} ; 58,59$ - length of $\mathrm{M}^{3}$ and $\mathrm{M}_{3} ; 60,61$ - width of $\mathrm{M}^{3}$ and $\mathrm{M}_{3}$; anl - anteroconul, an - anterocon, pn - protocon, pan - paracon, hn - hypocon, mn - metacon, and - anteroconid, pd - protoconid, md - metaconid, ed - entoconid, hd - hypoconid, hld hypoconulid; prf - protoflecsus, hpf — hypoflexus, parf_paraflexus, mtf — metaflexus (Meulen van der, 1973; Lawrence, 1991). 
A

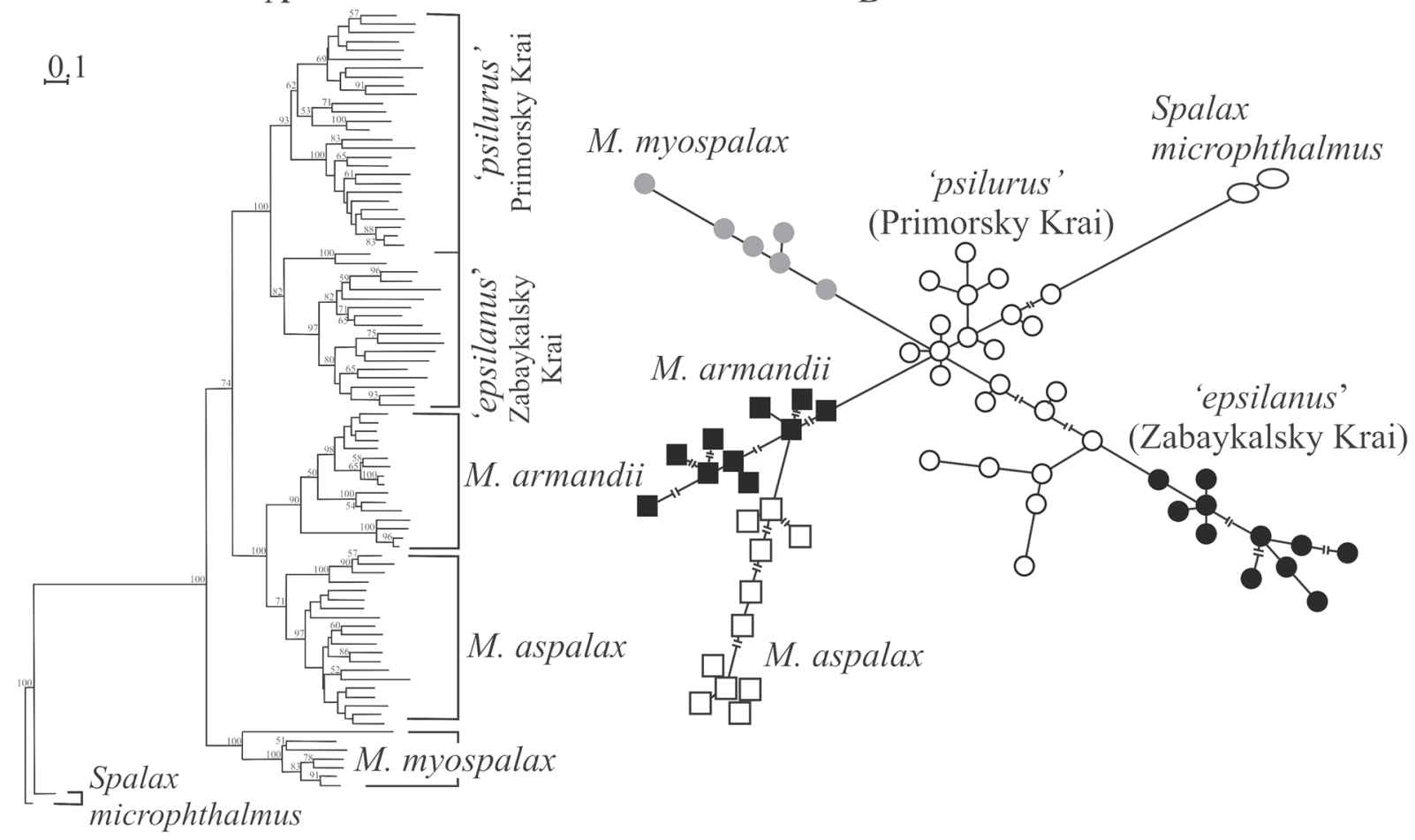

Figure 6. A, NJ and B, MST phylogenetic reconstructions based on the RAPD-PCR analyses of zokors. Numbers at the branching nodes represent bootstrap support values (\%) obtained from 1000 replicates (only the values exceeding 50\% are demonstrated).

got into 'epsilanus' cluster, while the specimen from Beijing got in 'psilurus' cluster. This result is clearly not an accidental division into two morphological groups that may indicate two subspecies taxa. According to this hypothesis, the zokors from Primorsky Krai and North-East China should belong to $M$.p. psilurus, but the zokors from Zabaykalsky Krai and North-West China - to M. p. epsilanus. In addition, we found out that the zokors from the Greater Khingan Mountains were significantly different from the zokors collected in Zabaykalsky Krai and Primorsky Krai by the length of the $M_{1}$ and $M_{2}$ and the total length of the upper toothrow (Fig. 10).

Morphological studies. We found the strong differences between zokors from Primorsky Krai and Zabaykalsky Krai by the shape of the suture (sutura incisi$v a$ ) between maxillary bone and premaxillary bones in the caudal part of the foramina incisiva (Fig. 11). Variants of the joints of maxillary and premaxillary bones in both forms are stable and hardly age-independent. In zokors from Zabaykalsky Krai there is a weak participation of the maxillary bones in the formation of caudal edge of incisive foramen. This is the result of proliferation backward of premaxillary processes. In zokors from Primorsky Krai such processes are poorly developed and often absent.

The diversity of the shape of sutura incisiva in zokors from Eastern Mongolia, North and North-East China is higher than in Zabaykalsky Krai and Primor- sky Krai (Fig. 12). There are morphological variations that can be referred to 'psilurus' (Greater Khingan, Gorigol station of the Chinese Eastern Railway, Harbin region) as well as to 'epsilanus' (Harbin region, Qiqihar (=Tsitsikar) and Hai-Bay stations of Chinese Eastern Railway). Among the animals from Beijing region we found only 'psilurus' type. Our material from China included 19 skulls, which belonged to 'epsilanus' type, and 12 skulls - to 'psilurus' type. So, the shape of sutura incisiva in these zokors is more diverse than in the both marginal populations from the Russian territory.

Zokors that are morphologically identical to zokors from Zabaykalsky Krai are also distributed in Eastern Mongolia (the Numurgingol River basin, Eastern District ('Aimag'), Western slope of the Greater Khingan).

Hence, there are possible ambiguity about 'psilurus' - 'epsilanus' identification by the quantitative criterions (skull measurements) and qualitative criterions (shape of the sutures). Therefore, overall, according to morphometric study major morphometric features of zokors from Zabaykalsky Krai are closer to the zokors from the North-East of China than to the zokors living in Primorsky Krai.

\section{Discussion and conclusion}

Karyotype variability. Spalacidae are known to be characterized by a wide range of chromosomal variability (Nevo et al., 2000). Consequently, resolving of 
Table 3. Spearman rank correlations between multidimensional scaling (MDS) axes (E1-E3 and K1-K3), and measurements of zokor skulls from 'psilurus - epsilanus' group $(n=91) ; r^{2}$, squared multiple correlation coefficients from multiple linear regression model. Descriptions of the measures see at the Fig. 3.

\begin{tabular}{|c|c|c|c|c|c|c|c|}
\hline Measurements & E1 & E2 & E3 & K1 & $\mathrm{K} 2$ & K3 & $r^{2}$ \\
\hline 1 & -0.96 & 0.07 & -0.05 & -0.46 & 0.23 & -0.38 & 0.95 \\
\hline 2 & -0.95 & 0.07 & 0.05 & -0.48 & 0.13 & -0.38 & 0.93 \\
\hline 3 & -0.89 & -0.09 & -0.03 & -0.32 & 0.17 & -0.55 & 0.87 \\
\hline 4 & -0.84 & 0.09 & -0.15 & -0.39 & 0.31 & -0.27 & 0.78 \\
\hline 5 & -0.62 & 0.20 & 0.28 & -0.54 & -0.06 & -0.45 & 0.62 \\
\hline 6 & -0.25 & -0.42 & -0.59 & 0.38 & 0.45 & -0.29 & 0.58 \\
\hline 7 & -0.34 & 0.45 & 0.34 & -0.61 & -0.23 & 0.36 & 0.71 \\
\hline 8 & -0.59 & -0.45 & 0.17 & 0.08 & -0.15 & -0.47 & 0.65 \\
\hline 9 & -0.65 & 0.23 & 0.14 & -0.57 & 0.03 & -0.18 & 0.65 \\
\hline 10 & -0.57 & 0.29 & -0.03 & -0.45 & 0.21 & -0.06 & 0.45 \\
\hline 11 & -0.35 & 0.33 & 0.29 & -0.56 & -0.22 & 0.06 & 0.47 \\
\hline 12 & -0.51 & 0.20 & 0.16 & -0.47 & -0.13 & -0.09 & 0.54 \\
\hline 13 & -0.81 & 0.06 & -0.06 & -0.40 & 0.21 & -0.36 & 0.68 \\
\hline 14 & -0.50 & -0.22 & -0.12 & 0.06 & 0.09 & 0.0 & 0.46 \\
\hline 15 & -0.50 & -0.39 & -0.32 & 0.22 & 0.28 & -0.06 & 0.57 \\
\hline 16 & -0.23 & -0.12 & -0.54 & 0.17 & 0.46 & 0.11 & 0.47 \\
\hline 17 & -0.76 & 0.10 & -0.15 & -0.36 & 0.29 & -0.32 & 0.62 \\
\hline 18 & -0.80 & 0.25 & 0.09 & -0.59 & 0.12 & -0.30 & 0.77 \\
\hline 19 & -0.44 & -0.08 & -0.40 & 0.0 & 0.47 & -0.19 & 0.42 \\
\hline 20 & -0.74 & -0.04 & -0.15 & -0.30 & 0.24 & -0.28 & 0.63 \\
\hline 21 & -0.93 & -0.02 & 0.00 & -0.39 & 0.17 & -0.47 & 0.91 \\
\hline 22 & -0.89 & 0.07 & 0.16 & -0.50 & 0.02 & -0.38 & 0.87 \\
\hline 23 & -0.04 & -0.43 & -0.19 & 0.41 & 0.03 & -0.32 & 0.31 \\
\hline 24 & -0.67 & -0.09 & 0.10 & -0.25 & 0.02 & -0.34 & 0.51 \\
\hline 25 & -0.63 & 0.06 & -0.34 & -0.22 & 0.47 & -0.18 & 0.58 \\
\hline 26 & -0.79 & -0.12 & -0.31 & -0.17 & 0.44 & -0.47 & 0.80 \\
\hline 27 & -0.73 & 0.23 & -0.14 & -0.51 & 0.39 & -0.24 & 0.68 \\
\hline 28 & -0.75 & 0.31 & 0.07 & -0.62 & 0.09 & -0.05 & 0.78 \\
\hline 29 & -0.64 & -0.11 & -0.02 & -0.18 & 0.13 & -0.25 & 0.47 \\
\hline 30 & -0.75 & 0.32 & 0.11 & -0.68 & 0.03 & -0.20 & 0.77 \\
\hline 31 & -0.79 & 0.27 & -0.11 & -0.55 & 0.28 & -0.06 & 0.79 \\
\hline 32 & -0.78 & 0.21 & -0.09 & -0.48 & 0.29 & -0.04 & 0.82 \\
\hline 33 & -0.83 & 0.17 & -0.13 & -0.47 & 0.34 & -0.22 & 0.84 \\
\hline 34 & -0.58 & -0.05 & -0.40 & -0.11 & 0.53 & -0.13 & 0.59 \\
\hline 35 & -0.87 & 0.18 & -0.05 & -0.49 & 0.22 & -0.35 & 0.82 \\
\hline 36 & -0.36 & 0.07 & -0.34 & -0.05 & 0.43 & 0.25 & 0.48 \\
\hline 37 & -0.24 & -0.15 & 0.17 & 0.06 & -0.13 & -0.05 & 0.21 \\
\hline 38 & -0.88 & 0.02 & 0.07 & -0.43 & 0.07 & -0.42 & 0.82 \\
\hline 39 & -0.80 & -0.19 & -0.28 & -0.10 & 0.39 & -0.40 & 0.80 \\
\hline 40 & -0.79 & 0.13 & -0.01 & -0.45 & 0.17 & -0.38 & 0.71 \\
\hline 41 & -0.66 & -0.20 & -0.35 & -0.03 & 0.45 & -0.39 & 0.67 \\
\hline 42 & -0.82 & 0.08 & -0.05 & -0.38 & 0.22 & -0.31 & 0.64 \\
\hline 43 & -0.68 & 0.12 & -0.10 & -0.36 & 0.31 & -0.23 & 0.60 \\
\hline 44 & -0.78 & -0.17 & -0.37 & -0.12 & 0.49 & -0.40 & 0.75 \\
\hline 45 & -0.59 & 0.07 & -0.05 & -0.30 & 0.21 & -0.27 & 0.45 \\
\hline 46 & -0.49 & 0.13 & 0.08 & -0.41 & -0.03 & -0.33 & 0.35 \\
\hline 47 & -0.59 & -0.41 & 0.25 & 0.07 & -0.15 & -0.28 & 0.65 \\
\hline 48 & -0.52 & -0.58 & -0.17 & 0.31 & 0.13 & -0.54 & 0.66 \\
\hline 49 & -0.41 & -0.22 & 0.04 & -0.05 & 0.05 & -0.54 & 0.44 \\
\hline 50 & -0.48 & -0.44 & 0.27 & 0.12 & -0.18 & -0.31 & 0.51 \\
\hline 51 & -0.43 & -0.43 & 0.22 & 0.11 & -0.18 & -0.56 & 0.60 \\
\hline 52 & -0.53 & -0.55 & -0.06 & 0.28 & 0.14 & -0.35 & 0.64 \\
\hline 53 & -0.38 & -0.60 & 0.04 & 0.42 & 0.0 & -0.29 & 0.53 \\
\hline 54 & -0.39 & -0.52 & 0.17 & 0.23 & -0.19 & -0.23 & 0.57 \\
\hline 55 & -0.49 & -0.50 & 0.28 & 0.11 & -0.25 & -0.53 & 0.70 \\
\hline 56 & -0.42 & -0.56 & -0.11 & 0.28 & 0.15 & -0.31 & 0.51 \\
\hline
\end{tabular}


Table 3 (continued).

\begin{tabular}{|l|c|c|c|c|c|c|c|}
\hline Measurements & E1 & E2 & E3 & K1 & K2 & K3 & $r^{2}$ \\
\hline 57 & -0.27 & -0.40 & 0.08 & 0.19 & -0.14 & -0.19 & 0.36 \\
\hline 58 & -0.47 & -0.29 & 0.46 & -0.08 & -0.43 & -0.13 & 0.54 \\
\hline 59 & -0.38 & -0.09 & 0.40 & -0.13 & -0.27 & 0.06 & 0.42 \\
\hline 60 & -0.26 & -0.35 & 0.27 & 0.11 & -0.20 & -0.17 & 0.27 \\
\hline 61 & -0.48 & -0.27 & 0.28 & -0.04 & -0.23 & -0.14 & 0.42 \\
\hline
\end{tabular}

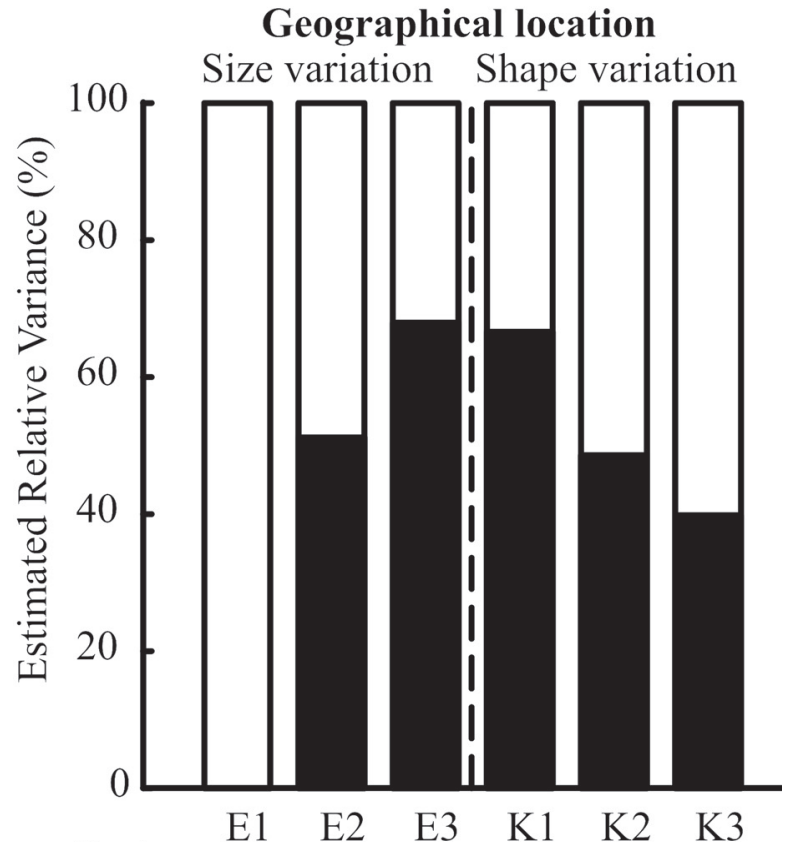

Factor

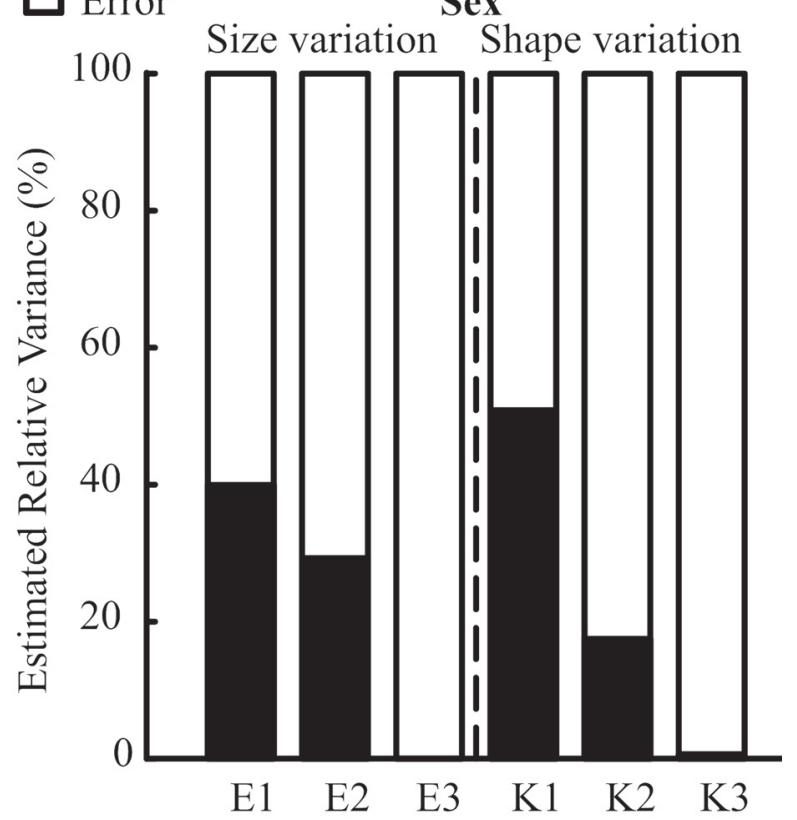

Figure 7. Relative variance components (\%) of six variables (MDS axes: E1-E3, K1-K3) which depend on two factors: geographical location (Zabaykalsky Krai or Primorsky Krai) and sex. taxonomic evaluation based on cytogenetic data is difficult. Zokors of the 'psilurus-epsilanus' group are not an exception. Unambiguous evaluation of taxonomic significance of differences in karyotype structure between marginal populations under study is complicated. It is only possible with integrated analysis by different methods and including the samples from China for the 'psilurus-epsilanus' group. Unfortunately, studies of karyotype structure of zokors from China are limited and include only a small number of individuals ( $\mathrm{Li} \&$ Chen, 1987).

For most species of Myospalacinae the analysis of population variability in karyotype structure was not performed. The exception is Altai zokor M. myospalax. Significant intra- and interpopulation polymorphism and the differences in karyotype structure between isolated populations and subspecies was shown for this species (Vorontsov \& Martynova, 1976).

The similarity of the dendrograms on Fig. 9A and Fig. 6A is a good evidence of conformity between genetic and morphological differentiation of 'psilurus' and 'epsilanus'. It is quite possible that the case for the group 'psilurus-epsilanus' can be considered as sustained differentiation, at least, on the subspecies level.

Genetic variability. The results of the analysis of proteins as biochemical markers of genes allow concluding that the blood transferrin protein variants can be used as genetic markers for chromosomal forms and geographically fragmented populations. Thus, all samples of North China zokor from Primorsky Krai (' $p$ silurus') were found to be monomorphic by TF-B, while the samples from Zabaykalsky Krai ('epsilanus') possessed TF-C only. The analysis of several local samples from different parts of the area and for different years were carried out, therefore stronger evidence for existence of fixed genetic differences in the TF locus between these two forms was obtained. Taking into consideration the samples from two locations which had been studied earlier (Martynova et al., 1977), we can assume that the earlier observed difference by transferrin variants reflects real genetic differentiation between Zabaykalsky Krai and Primorsky Krai populations.

Any genetic data for the main part of the range, covering the North-East China and Eastern Mongolia, are absent. This fact does not allow us to evaluate the taxonomical 'weight' of differences by variants of transferrins between marginal populations from the Russian territory by the viewpoint of biological species concept in full measure.

Taxonomic interpretation of such differences is usually ambiguous. There are numerous examples in dif- 
Table 4. Significance of morphological differences within the 'psilurus - epsilanus' group $\left(\chi^{2}\right.$ - median test, $\mathrm{M}$ - mean, $\mathrm{m}$ - standard error).

\begin{tabular}{|c|c|c|c|c|c|c|}
\hline \multirow[t]{2}{*}{ Measurements } & \multirow[t]{2}{*}{$\chi^{2}, d f=1$} & \multirow[t]{2}{*}{$p$} & $\mathrm{M}$ & $\mathrm{m}$ & $\mathrm{M}$ & $\mathrm{m}$ \\
\hline & & & \multicolumn{2}{|c|}{ 'psilurus' } & \multicolumn{2}{|c|}{ ‘epsilanus' } \\
\hline 6 & 30.5 & $<0.0001$ & 5.7 & 0.05 & 5.0 & 0.07 \\
\hline 7 & 22.4 & $<0.0001$ & 8.8 & 0.08 & 9.7 & 0.11 \\
\hline 11 & 11.1 & 0.001 & 17.2 & 0.10 & 17.9 & 0.14 \\
\hline 53 & 8.8 & 0.003 & 2.4 & 0.02 & 2.3 & 0.03 \\
\hline 48 & 7.4 & 0.006 & 3.6 & 0.03 & 3.4 & 0.05 \\
\hline 16 & 6.7 & 0.009 & 4.6 & 0.04 & 4.3 & 0.06 \\
\hline 9 & 6.4 & 0.01 & 9.5 & 0.07 & 10.1 & 0.17 \\
\hline 58 & 6.3 & 0.01 & 2.7 & 0.02 & 2.8 & 0.04 \\
\hline 12 & 5.8 & 0.02 & 19.7 & 0.11 & 20.2 & 0.16 \\
\hline 18 & 5.8 & 0.02 & 16.5 & 0.11 & 17.4 & 0.22 \\
\hline 28 & 5.8 & 0.02 & 13.4 & 0.10 & 13.9 & 0.16 \\
\hline 21 & 5.8 & 0.02 & 29.7 & 0.18 & 31.3 & 0.37 \\
\hline 41 & 5.1 & 0.02 & 12.0 & 0.09 & 11.3 & 0.18 \\
\hline 56 & 4.5 & 0.03 & 2.2 & 0.01 & 2.1 & 0.02 \\
\hline 46 & 4.3 & 0.04 & 6.6 & 0.04 & 6.7 & 0.13 \\
\hline 30 & 4.2 & 0.04 & 12.2 & 0.09 & 12.9 & 0.16 \\
\hline
\end{tabular}

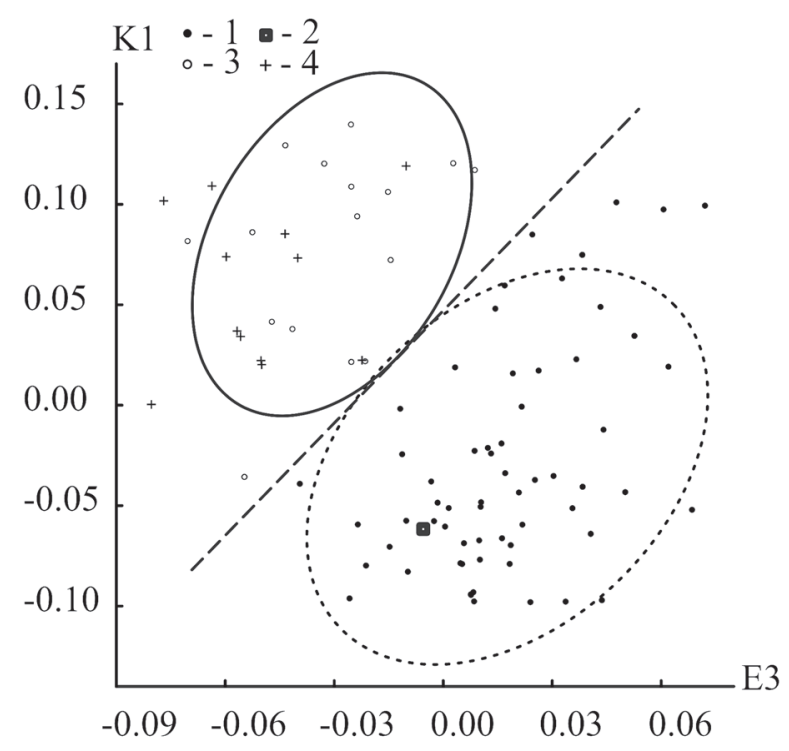

Figure 8. Bivariate plots of the MDS axes (E3 and K1) for all the zokors 'psilurus - epsilanus': 1 - Primorsky Krai; 2 suburbs of Beijing (China); 3 - Zabaykalsky Krai; 4 Northern China.

ferent groups of rodents where fixed genetic differences in the TF locus are represented both among subspecies and in closely related species (Vorontsov et al., 1978; Frisman \& Vorontsov, 1989; Mezhzherin, 1996; Mezhzherin et al., 1999).

Marginal populations from Zabaykalsky Krai and Primorsky Krai have significant differences according to RAPD-PCR results of the study. The observed quantitative and qualitative features of the variability of these populations show a high degree of genetic differentiation comparable to that in M. aspalax and $M$. armandii pair (Pavlenko \& Korablev, 2003a). That allows estimating these differences as corresponding to interspecies level. A similar pattern of differentiation is detected by sequencing of mitochondrial markers: hypervariable region D-loop and cytochrome $b$ (Tsvirka et al., 2009a).

Morphological variability. The main morphological differences within the 'psilurus-epsilanus' group were found in hard palate features (foramina incisiva, length of maxillary bone), and several other measurements.

Most probably, zokors in the territory of Primorsky Krai are identical to the zokors living in the southern part of the range of 'psilurus - epsilanus' group (Fig. 13). We found that the zokor from the suburbs of Beijing ('typical psilurus', potentially) is almost identical to the animals from the Khanka Plain (Primorsky Krai). Thereby, the hypothesis about identity of zokors from marginal northeastern population and $M$. p. psilurus from the suburbs of Beijing has justification that is more convincing after this study.

Zheng (1994) attracted attention to the foramina incisiva size and to their position relative to intermaxillary and maxillary bones as an important taxonomic feature in Myospalacinae. According to this author (Zheng, 1994: 25), the position of the sutura intermaxillaris relative to incisive foramen in M. psilurus corresponds exactly to that found by us in the zokors from Primorsky Krai. The length of foramina incisiva (in percentage of the length of upper diastem) in these populations is $39.9 \pm 0.36 \%$. Zheng (1994) does not report the variant of the shape of sutura intermaxillaris, when the premaxillary bones almost completely form the foramina incisiva. We observed this variant in populations from Zabaykalsky Krai of Russia, Mongolia and North-East China. The relative size of foramina incisiva in zokors from Zabaykalsky Krai is $33.8 \pm 0.59 \%$. 


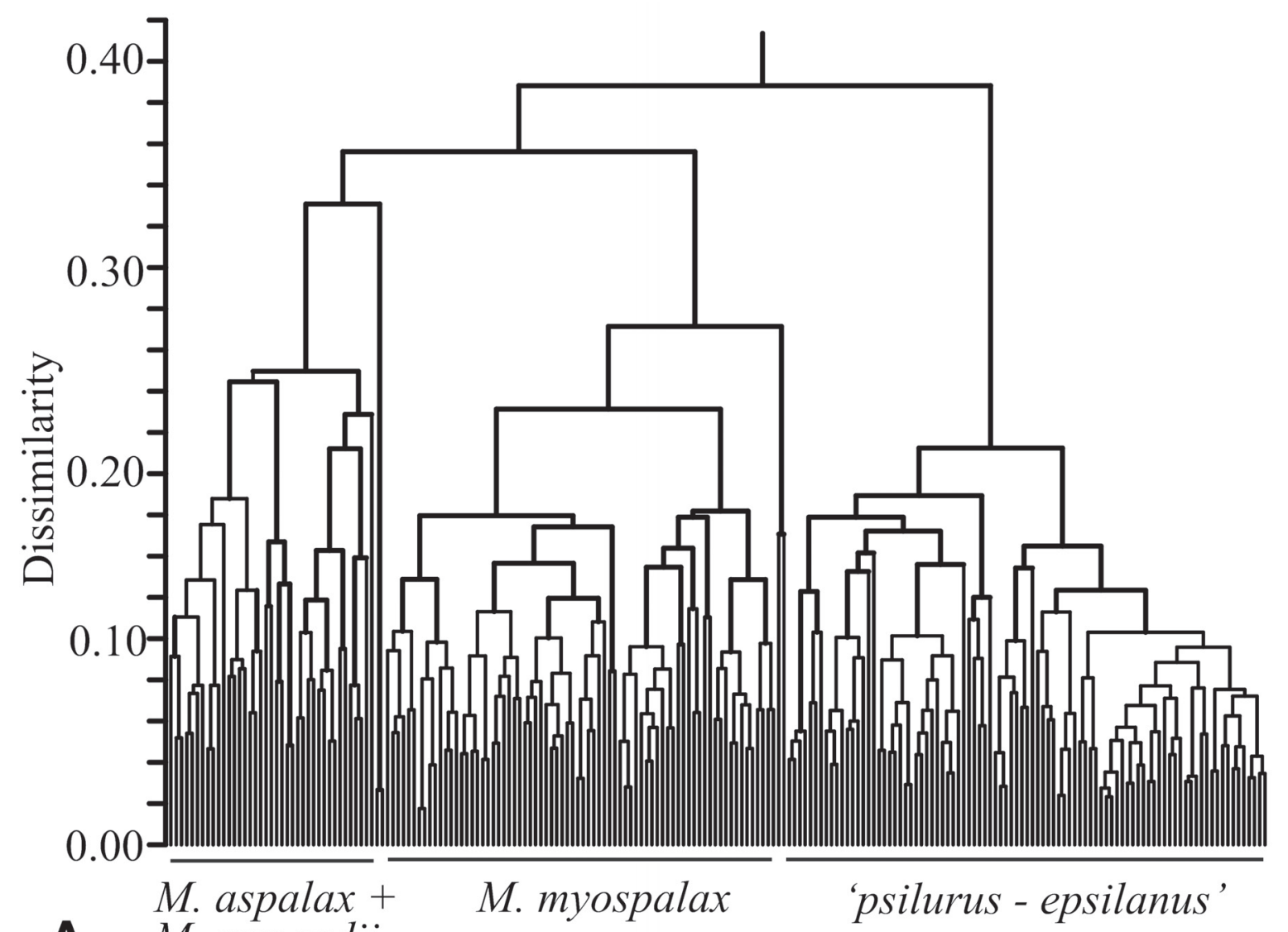

A M. armandii

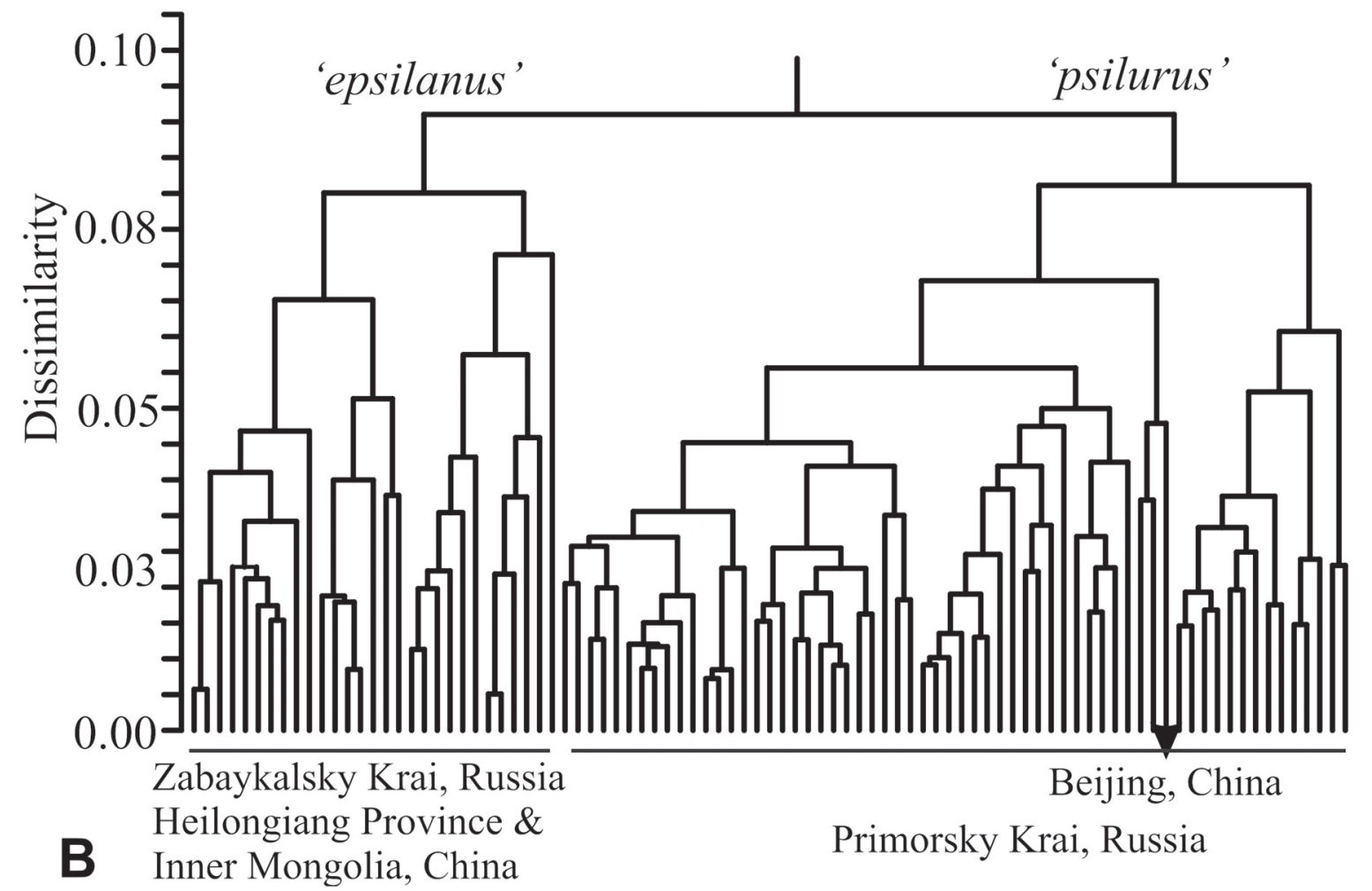

Figure 9. A - UPGMA zorkors' morphological classification based on the MDS axes (from Puzachenko et al., 2009, with modification); B - UPGMA dendrogram of 'psilurus - epsilanus' group. 


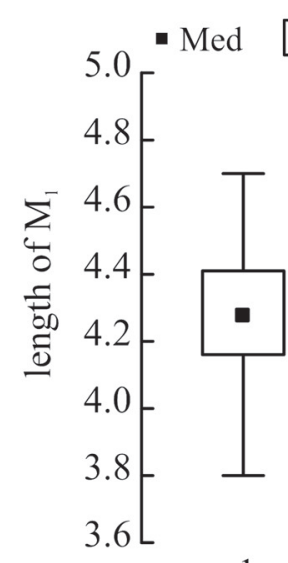

1

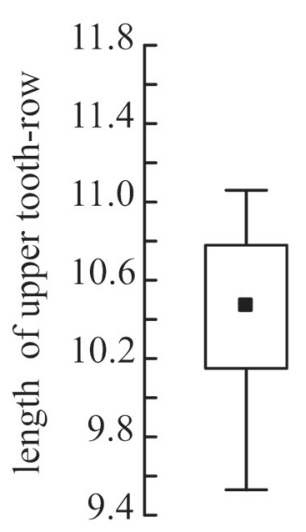

1

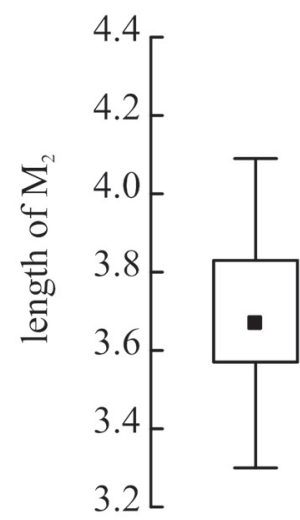

1

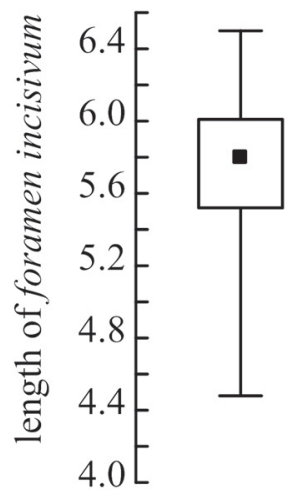

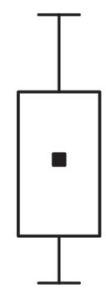

2

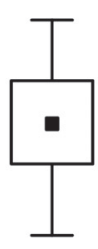

2

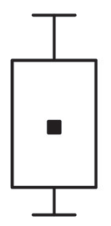

2

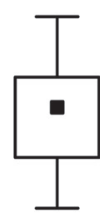

3
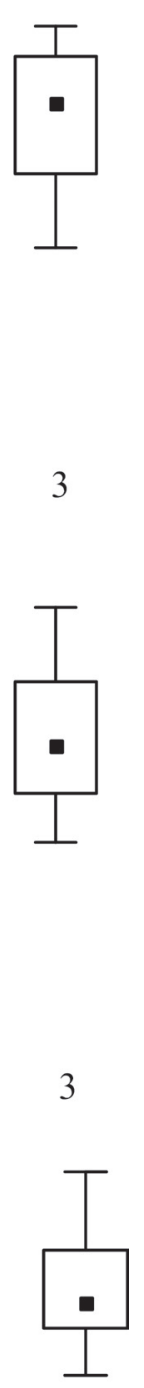

3

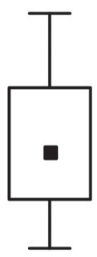

3

A

B
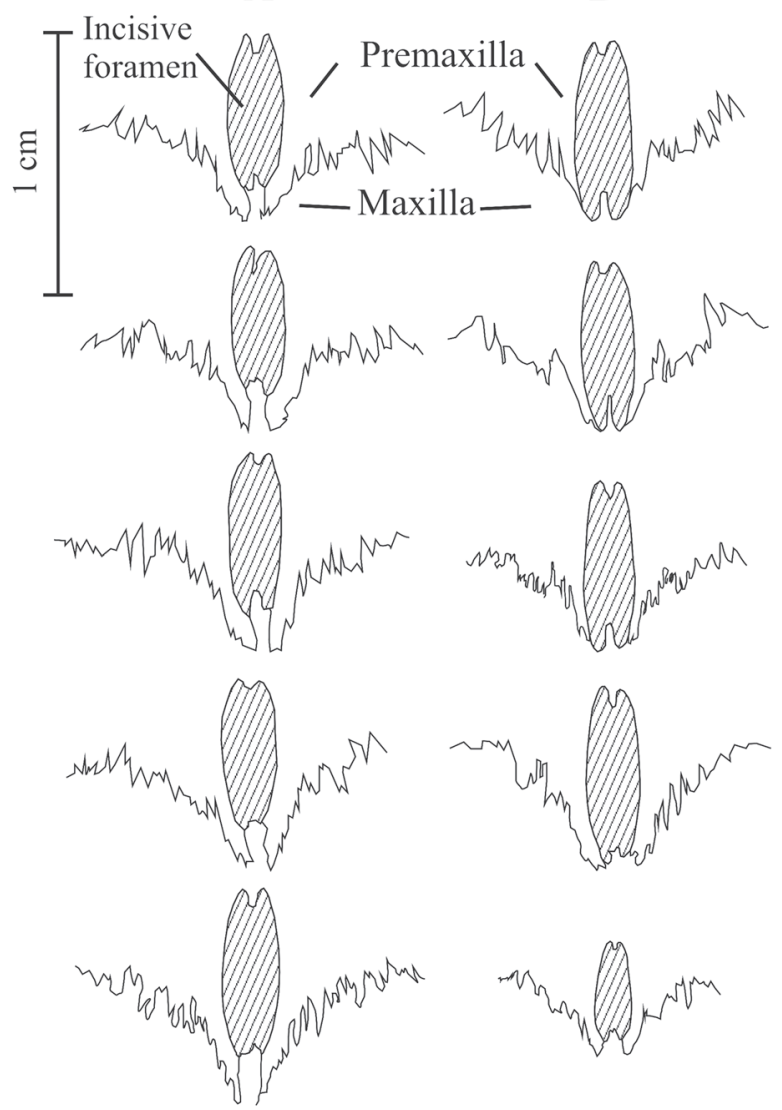

Figure 11. Variants of shape of sutura incisiva in the 'psilurus - epsilanus' group: A — Zabaykalsky Krai; B — Primorsky Krai (IBSS).

There are significant differences $(F=62.2, p<0.00001)$ from the Primorsky Krai zokors. On this feature, zokors from North China, including the Greater Khingan, take up an intermediate position (36.6 $\pm 0.88 \%)$. According to statistical criteria these zokors are closer to the zokors from Zabaykalsky Krai, but still differ from them $(F=$ $7.5, p=0.01)$. They differ significantly from zokors inhabiting the east of the range, $(F=33.1, p<0.00001)$. This difference corresponds well to the results of multivariate morphometric analysis.

These results of morphological studies oblige us to propose a more complicated scheme of differentiation within 'psilurus-epsilanus' zokors. In terms of the taxonomy, the zokor living in Great Khingan region (eastward of Zabaykalsky Krai) must be considered as M. $p$. epsilanus. In this case, we take into account that the terra typica of $M$. epsilanus is the Greater Khingan Range. Thus, the estimated M. p. epsilanus range prob-

Figure 10. The features of zokors from the suburbs of Beijing, Primorsky Krai (1) related to zokors from Zabaykalsky Krai (2) and Greater Khingan and suburbs of Harbin (China) (3). Med - median value, 25-75\% — quartiles, Min - Max minimum and maximum values. 

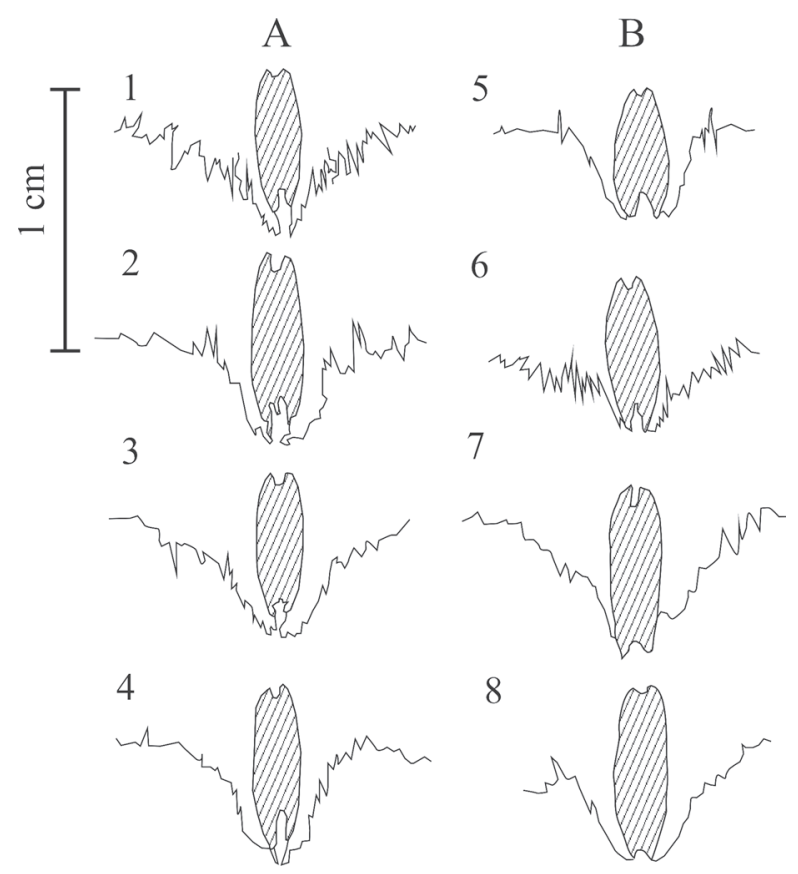

8

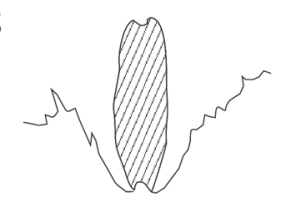

Figure 12. Variants of shape of sutura incisiva in 'psilurus epsilanus' group from the territory of Mongolia and China. A - 'epsilanus' type: 1 - Numurgingol River basin, Eastern Aimag: S-166734 (ZMMU); 2-4 - Xiaolin (Chinese Eastern Railway), suburbs of Harbin: S-83783, S-83778, S83774 (ZMMU); B - 'psiluirus' type: 5 - Xiaolin (Chinese Eastern Railway), suburbs of Harbin: S-83782 (ZMMU); 6 - Yalu (Chinese Eastern Railway), Greater Khingan: S83775 (ZMMU); 7-8 — suburbs of Beijing: S-165144, S77109 (ZMMU).

ably covers the territory from the Hailar River (upper Argun River) and Greater Khingan watershed to the basin of the Nenjiang River (left tributary of the Sungari River) and the middle course of the Sungari River (Fig. 13). According to available data, we cannot describe the southern and eastern boundary of the range of M. p. epsilanus. As a hypothesis, we consider the Mudanjiang River in Heilongdjiang Province of China as the eastern border and as the southern border - the upstream of the Sungari River in Jilin Province. To the northwest from $M$. p. epsilanus in Zabaykalsky Krai (Russia) and Eastern Mongolia a form with uncertain status is distributed (Fig. 13). This form is definitely close to M. p. epsilanus by the morphometric data, but has some specific features in foramina incisiva construction, the length of the $\mathrm{M}_{1}$ and $\mathrm{M}_{2}$ and the total length of the upper tooth-row. We propose to consider provisionally this form as a separate subspecies of the North China zokor until genetic investigation of the zokors from the Chinese territory is done. The right bank of the Argun River and the western slope of Greater Khingan (Russia, Mongolia, and China (?)) probably limit the range of this form.

Both the M. p. epsilanus and form from Zabaykalsky Krai (Russia) and Eastern Mongolia differ well from the zokors inhabiting Primorsky Krai by the morphological features, and zokors from Zabaykalsky Krai, at least, have strong difference from Primorsky Krai ones by the karyotype and genetic features. According to morphological data, there are not any evidences that zokors from Primorsky Krai differ from the typical North China zokor described from the suburbs of Beijing. Therefore, we include the zokors from Primorsky Krai into M. p. psilurus subspecies (Fig. 13) until the new genetic/morphological data are accessible.

In earlier studies (Lawrence, 1991; Pavlenko \& Korablev, 2003a; Tsvirka et al., 2011) it was suggested that M. psilurus and M. epsilanus are well-separated species by morphologic, genetic and karyotypic features. Overall, presented results do not contradict this hypothesis, but new evidences need to test it in the full. For the further revision, integrated genetic-morphological research of the zokors from the Chinese part of the species range is necessary to be done.

ACKNOWLEDGMENTS. We are grateful to the curators of mammals collection I. Pavlinov (ZMMU, Moscow), G. Baranova (ZIN, Saint Petersburg) for giving access to their collections used in this study. We thank the staff of Daurian State Nature Reserve (Russia), especially Vadim Kiriliuk and Yuri Bazhenov, for assistance in field work. Authors are profoundly grateful to Nikolai Formozov for the very intentionality criticism of our study content and useful remark of manuscript. This study was supported by the Russian Foundation for Basic Research (grants Nos 09-04-01303 and 12-04-00795).

\section{References}

Abramov A.V., Puzachenko A.Yu. 2005. Sexual dimorphism of craniological characters in Eurasian badgers, Meles spp. (Carnivora, Mustelidae) // Zoologischer Anzeiger. Vol.244. P.11-29.

Abramov A.V., Puzachenko A.Yu., Wiig Ø. 2009. Cranial variation in the European badger Meles meles (Carnivora, Mustelidae) in Scandinavia // Zoological Journal of Linnean Society. Vol.157. P.433-450.

Allen J.A. 1909. Mammals from Shen-Si province China // Bulletin of the American Museum of Natural History. Vol.26. P.425-430.

Allen G.M. 1938. The mammals of China and Mongolia // Bulletin of the American Museum of Natural History. Vol.1. Part 1. P.1-620.

Baryshnikov G.F., Puzachenko A.Yu. 2011. Craniometrical variability of cave bears (Carnivora, Ursidae) // Quaternary International. Vol.245. P.350-368.

Cai Z., Zhang T., Ci H., Tang L., Lian X., Liu J., Su J. 2007. Mitochondrial phylogeography and genetic diversity of plateau zokor (Myospalax baileyi) // Acta Zoologica Sinica. Vol.27. No.2. P.130-137.

Carleton M.D., Musser G.G. 2005. Order Rodentia // Wilson D.E. \& Reeder D.M. (eds.). Mammal Species of the World. Third edition. Baltimore: The Johns Hopkins University Press. P.745-752. 


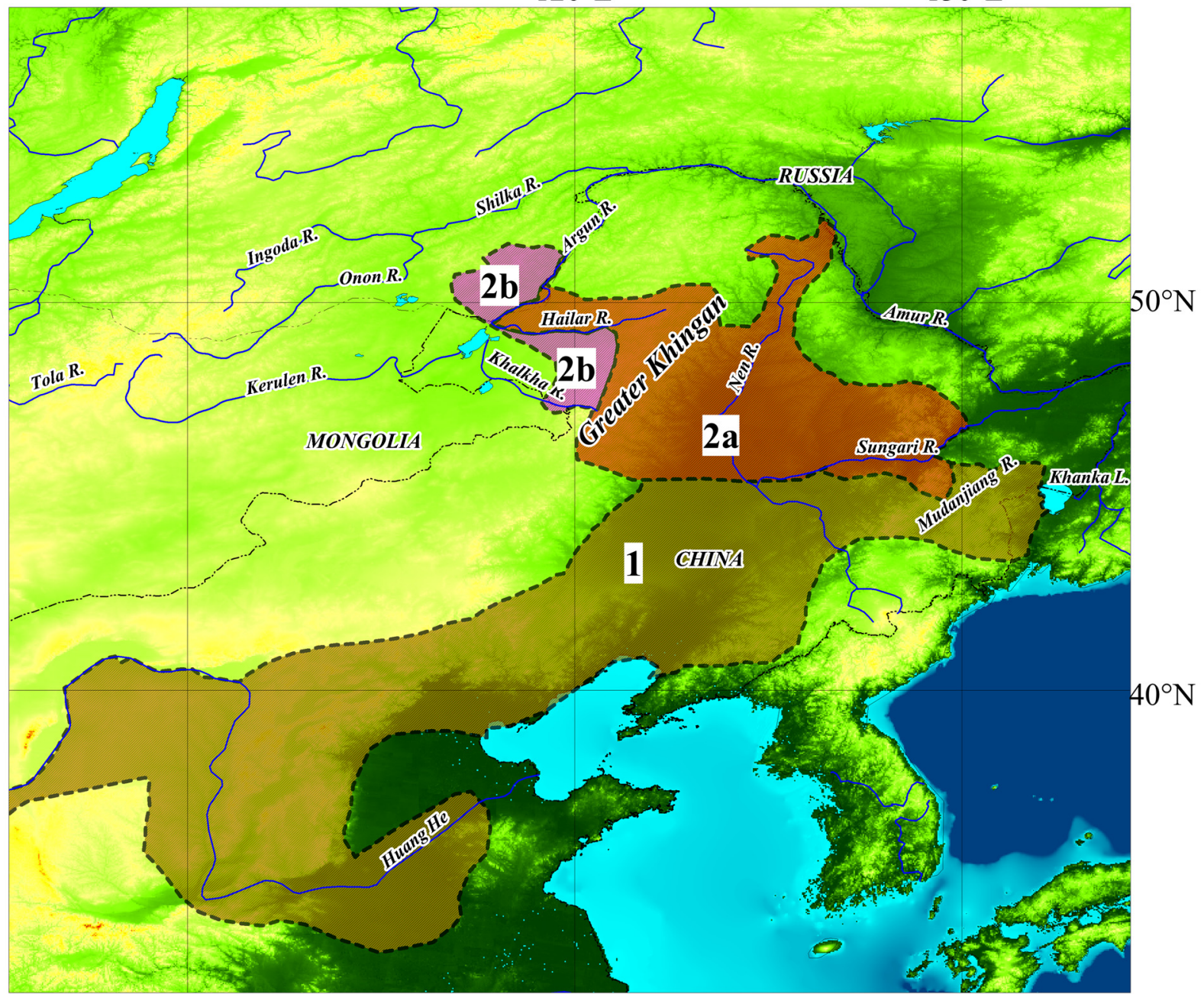

Figure 13. Scheme of supposed range of the North China zokor, M. psilurus: $1-$ M. p. psilurus; $2 \mathrm{a}-$ M. p. epsilanus; $2 \mathrm{~b}-$ M. p. ssp.

Chelomina G.N., Korablev V.P., Pavlenko M.V. 2011. Genetic Diversity and phylogenetic relationschips of the Manchurian zokor Myospalax psilurus (Rodentia, Muridae) according to RAPD-PCR analysis // Biology Bulletin. No.38. P.222-230.

Chelomina G.N., Spiridonova L.N., Korablev V.P., Pavlenko M.V., Zhuravlev Yu.N. 2003. Rare species of the Russian Far East: RAPD-PCR analysis of genetic diversity of Amur tiger Panthera tigris altaica and Manchurian zokor Myospalax psilurus epsilanus populations // Proceedings of the IV European Congress of Mammalogy, Brno. P.80.

Davison M.L., Jones L.E. 1983. Special issue: multidimensional scaling and its applications. Applied Psychological Measurement. Vol.7. P.373-514.

Fan N.-C., Shi Y. 1982. A revision of the zokors of subgenus Eospalax // Acta Zoologica Sinica. No.2. P.83-199.

Flynn L.J. 2009. The antiquity of Rhizomys and independent acquisition of fossorial traits in subterranean muroids //
Bulletin of the American Museum of Natural History. No.331. P.128-156.

Fomicheva I.I. 1973. [Certain aspects of investigation of the genetic polymorphism of transferrins and postalbumins in cattle] // Russian Journal of Genetics. No.9. P.59-66 [in Russian with English summary].

Ford C.E., Hamerton J.L. 1956. A colchicines hypotonic citrate squash sequence for mammalian chromosome // Stain Technology. No.31. P.247-251.

Frisman L.V., Vorontsov N.N. 1989. [Genogeographical variability of the long-tailed ground squirrel Citellus undulatus Pallas] // Kryukov A.P., Chelomina G.N. \& Pavlenko M.V. (eds.). [The Present-Day Approaches to Studies of Variability]. Vladivostok: IBSS FEB RAS. P.43-46 [in Russian with English summary].

Galkina L.I., Nadeev I.V. 1980. [Some questions of morphology, distribution and history of the zokors (Rodentia, Myospalacinae) of Western Siberia] // [Fauna and Ecology of Vertebrates of Siberia]. Proceedings of the 
Biological Institute of the SB AS USSR. No.44. Novosibirsk: Nauka. P.162-176.

Gromov I.M., Erbaeva M.A. 1995. [The Mammals of Russia and Adjacent Territories. Lagomorphs and Rodents]. Sankt-Peterburg: Zoologicheskii Institut Rossiiskoi Akademii Nauk. 522 p. [in Russian].

Jansa S.A., Weksler M. 2004. Phylogeny of muroid rodents: relationships within and among major lineages as determined by IRBP gene sequences// Molecular Phylogenetics and Evolution. Vol.31. No.1. P.256-276.

Jansa S.A., Giarla T.C., Lim B.K. 2009. The phylogenetic position of the rodent genus Typhlomys and the geographic origin of Muroidea // Journal of Mammalogy. Vol.90. No.5. P.1083-1094.

Korablev V.P., Pavlenko M.V. 2004. [Current state and protection of the population of the Transbaikalian zokor Myospalax psilurus the Southern Russian Far East] // [Proceedings of the Siberian Zoological Conference]. Novosibirsk. P.142-143 [in Russian].

Korablev V.P., Pavlenko M.V. 2007a. [Cytogenetical characters and geographic distribution of zokors (Myospalax) in Transbaikalia] // [The Theriofauna of Russia and Neighboring Areas. Proceedings of the International Conference]. Moskva: Nauka. P.216 [in Russian].

Korablev V.P., Pavlenko M.V. 2007b. [Genetic characteristics and geographic distribution of zokors Myospalax (Rodentia) in South Transbaikalia] // [Environmental Cooperation Between Chita Oblast (Russian Federation) and Inner Mongolia (People Republic of China) in Transboundary Ecological Regions. Proceedings of the International Conference]. Chita. P.188-190 [in Russian].

Korablev V.P., Pavlenko M.V., Puzachenko A.Y., Tsvirka M.V. 2009. [Integrated study of zokors (Myospalax) from Russian part of the Amur Basin] // [III Readings from Druzhinin: Integrated Studies for Environment in the Amur Basin: Proceedings of the Inter-regional Researche Conference]. Khabarovsk: FEB RAS. P.198200 [in Russian].

Kostenko V.A. 1970. [Manchurian zokor in Primorsky Krai] // [Small Mammals of Priamurye and Primorye]. Vladivostok: FEB RAS. P.170-175 [in Russian].

Kostenko V.A. 1989. [Manchurian zokor (Myospalax psilurus epsilanus Thomas, 1907)] // [Rare Vertebrate Animals of the Soviet Far East and Their Protection]. Leningrad: Nauka. P.184-185 [in Russian].

Kostenko V.A., Korablev V.P. 2005. [The Transbaikalian zokor - Myospalax psilurus epsilanus Thomas, 1912] // Kostenko V.A. (ed.). Krasnaya Kniga Primorskogo Kraya: Zhivotnye [Red Data Book of Primorsky Krai: Animals]. Vladivostok: Apel'sin. P.363-365 [in Russian].

Kruskal J.B. 1964. Multidimensional scaling by optimizing goodness of fit to a nonmetric hypothesis // Psychometrika. Vol.29. P.1-27.

Kupriyanova I.F., Puzachenko A.Y., Agadzanyan A.K. 2003. [Temporal and spatial patterns of craniological variation in common shrew, Sorex araneus (Insectivora)] // Zoologicheskii Zhurnal. Vol.82. No.7. P.839-851 [in Russian with English summary].

Lawrence M.A. 1991. A fossil Myospalax cranium (Rodentia, Muridae) from Shanxi, China, with observations on zokor relationships // Griffiths T.A. \& Klingener D. (eds.). Contributions to Mammalogy in Honor of Karl F. Koopman // Bulletin of the American Museum of Natural History. No.206. P.261-286.

Lee M.N., Elder F.B. 1980. Yeast stimulation of bone marrow mitosis for cytogenetics investigation // Cytogenetics and Cell Genetics. No.26. P.36-40.

Li B.G., Chen F.G. 1987. A comparative study of the karyotypes and LDH isoenzymes from some zokors of the subgenus Eospalax, genus Myospalax // Acta Theriologica Sinica. No.4. P.275 -286.

Lin G.-H., Wang K., Deng X.-G., Nevo E., Zhao F., Su J.-P., Guo S.-C., Zhang T.-Z., Zhao H. 2014. Transcriptome sequencing and phylogenomic resolution within Spalacidae (Rodentia) // BMC Genomics. Vol.15. P.32.

Martynova L.Ya. 1975. [Population cytogenetics of zokors (Myospalacinae, Rodentia)] // Systematics and Cytogenetics of Mammals]. Moskva: Nauka. P.13-15 [in Russian].

Martynova L.Ya. 1976. [Chromosomal differentiation of three species of zokors (Rodentia, Myospalacidae)] // Zoologicheskii Zhurnal. Vol.55. P. 1265-1268 [in Russian with English summary].

Martynova L.Ya. 1978. [Comparative Cytogenetics and Species Limits of Two Groups of Fossorial Mammals]. PhD Thesis. Moscow (in Russian).

Martynova L.Ya., Fomicheva I.I., Vorontsov N.N. 1977. [An electrophoretic study of blood proteins in three species of zokors (Myospalacinae, Rodentia)] // Zoologicheskii Zhurnal. Vol.56. P.1538-1542 [in Russian with English summary].

McKenna M.C., Bell S.K. 1997. Classification of Mammals Above the Species Level. New York: Columbia University Press. $640 \mathrm{p}$.

Meulen A.J. van der. 1973. Middle Pleistocene smaller mammals from the Monte Peglia (Orvieto, Italy) with special reference to the phylogeny of Microtus (Arvicolidae, Rodentia) // Quaternaria. Vol.17. P.1-144.

Mezhzherin S.V. 1996. Genetic relationships and systematical identity of Pamiro-Alay wood mouse Apodemus sylvaticus pallipes (Rodentia, Muridae) // Biology Bulletin. Vol.23. P.30-39.

Mezhzherin S.V., Brandler O.V., Lyapunova E.A., Morozov-Leonov S.Y., Vorontsov N.N. 1999. [Genetic relationships and differentiation in ground squirrels Marmotinae Pocock, 1923 (Rodentia, Sciuridae) from Palearctics] // Russian Journal of Genetics. No.35. P.756-764 [in Russian with English summary].

Miller M.P. 1997. Tools for population genetic analysis (TFPGA) 1.3: a Windows program for the analysis of allozyme and molecular population genetic data. Computer software distributed by author.

Nevo E., Ivanitskaya E., Filippucci M.G., Beiles A. 2000. Speciation and adaptive radiation of subterranian mole rats, Spalax ehrenbergi superspecies, in Jordan // Biological Journal of the Linnean Society. Vol.69. P.263281.

Norris R.W., Zhou K.Y., Zhou C.Q., Yang G., Kilpatrick C.W., Honeycutt R.L. 2004. The phylogenetic position of the zokors (Myospalacinae) and comments on the families of muroids (Rodentia) // Molecular Phylogenetics and Evolution. Vol.31. P.972-978. 
Nowak R.M. 1999. Walker's Mammals of the World. Sixth edition. Baltimore: the Johns Hopkins University Press. $936 \mathrm{p}$.

Ognev S.I. 1947. [Animals of the USSR and Adjacent Countries]. Vol.5. [Rodents]. Moskva: Akademiya Nauk SSSR. 809 p. [in Russian].

Pasteur N., Pasteur G., Bonhomme F., Catalan J., BrittonDavidian J. 1988. Practical Isozyme Genetics. Chichester: Halsted Press. 215 p.

Pavlenko M.V., Korablev V.P. 1999. [Genetic typing of Manchurian zokor Myospalax psilurus] // [Proceedings of the 6th Congress of Theriological Society of Russia]. Moskva: Severtsov Institute of Ecology and Evolution. P.188 [in Russian].

Pavlenko M.V., Korablev V.P. 2003a. [Genetic differentiation, systematic position and problem of conservation of the Manchurian zokor Myospalax psilurus (Rodentia, Myospalacinae) marginal population] // [The Theriofauna of Russia and Neighboring Areas. Proceedings of the International Conference]. Moscow: Severtsov Institute of Ecology and Evolution. P.51 [in Russian].

Pavlenko M.V., Korablev V.P. 2003b. [Genetic differentiation, systematic position and conservation of peripheral populations of Manchurian zokor Myospalax psilurus (Rodentia, Myospalacinae)] // Kryukov A.P. \& Yakimenko L.V. (eds.). [Problems of Evolution]. Vol.5. Vladivostok: Dal'nauka. P.167-177 [in Russian with English summary].

Pavlenko M.V., Korablev V.P. 2005. [Genetic diversity and geographic distribution of zokor Myospalax (Rodentia) in southern Transbaikalia] // [Ecosystems of Mongolia and Frontier Areas of Adjacent Countries: Natural Resources, Biodiversity and Ecological Prospects. Proceedings of the International conference]. Ulaanbaatar: Publishing House 'Bembi San'. P.300-302 [in Russian].

Pavlenko M., Korablev V., Tsvirka M., Pang J. 2008. Genetic differentiation of zokors (Rodentia, Myospalacinae) from East Russia: protein electrophoretic markers, karyological and molecular data // Eleventh International Conference on Rodent Biology, Rodens et Spatium. Myshkin. P.57.

Pavlinov I.Ya., Rossolimo O.L. 1987. [Systematics of Mammals of the USSR]. Moskva: MGU. 258 p. [in Russian].

Pavlinov I.Ya., Rossolimo O.L. 1998. [Systematics of Mammals of the USSR: Addition]. Moskva: MGU. 190 p. [in Russian].

Puzachenko A.Y. 2001. [Skull variability in the common mole rat Spalax microphthalmus (Spalacidae, Rodentia). 1. A method for analysis of data, non-age variability in males] // Zoologicheskii Zhurnal. Vol.80. No.3. P.343357 [in Russian with English summary].

Puzachenko A.Y. 2006. [Variability of the skull in the lesser mole rats, Nannospalax Palmer, 1903 (Rodentia)] // Zoologicheskii Zhurnal. Vol.85. No.2. P.235-253 [in Russian with English summary]

Puzachenko A.Y., Pavlenko M.V., Korablev V.P. 2009. [Variability of skulls in zokors (Rodentia, Myospalacidae)] // Zoologicheskii Zhurnal. Vol.88. No.1. P.92112 [in Russian with English summary].

Puzachenko A.Y., Pavlenko M.V., Korablev V.P., Tsvirka M.V. 2011. [Armand's zokor Myospalax armandii (Mil-
ne-Edwards, 1867) - new species in fauna of Russia] // [The Theriofauna of Russia and Neighboring Areas. Proceedings of the International Conference]. Moskva: Nauka. P.387 [in Russian].

Saitou N., Nei M. 1987. The neighbor-joining method: A new method for reconstructing phylogenetic trees // Molecular Biology and Evolution. Vol.4. P.406-425.

Sambrook J., Fritsch E.F., Maniatis T. 1989. Molecular Cloning: A Laboratory Manual. Cold Spring Harbor, NY: Cold Spring Harbor Laboratory Press.

Searle S.R., Casella G. \& McCulloch C.E. 1992. Variance Components. New York: John Wiley \& Sons. 501 p.

Smith A.T., Xie Y. 2008. A Guide to the Mammals of China. Princeton and Oxford: Princeton University Press. 544 p.

Sneath P.H.A., Sokal R.R. 1973. Numerical Taxonomy: the Principles and Practice of Numerical Classification. San Francisco: Freeman. 573 p.

Tsvirka M., Pavlenko M., Korablev V., Pang J. 2009a. Molecular-genetic relationships of the zokors (Rodentia, Myospalacinae): analysis of D-loop region polymorphism // Modern Achievements in Population, Evolutionary and Ecological Genetics (MAPEEG - 2009). Proceedings of the International Symposium. Vladivostok. P.48.

Tsvirka M.V., Pavlenko M.V., Korablev V.P. 2009b. [Genetic differentiation and phylogenetics relations of zokors (Rodentia, Myospalacinae) inferred from molecular-genetic analysis] // [Proceedings of 5th Meeting of Vavilov Society of Genetics and Breeders]. Part 2. Moskva: Rossiiskii Gosudarstvennyi Agrarnyi Universitet. P.307 [in Russian].

Tsvirka M.V., Pavlenko M.V., Korablev V.P. 2011. Genetic diversity and phylogenetic relationships in the zokor subfamily Myospalacinae (Rodentia, Muridae) inferred from RAPD-PCR // Russian Journal of Genetics. Vol.47. No.2. P.205-215.

Van de Peer Y., De Wacher R. 1994. TREECON for Windows: a software package for the construction and drawing of evolutionary trees for the Microsoft Windows environment // Computer Applications in the Biosciences. No.10. P.569-570.

Vorontsov N.N., Martynova L.Ya. 1976. [Population cytogenetics of Myospalax myospalax Laxm. (Rodentia, Myospalacidae)] // Doklady Akademii Nauk. Vol.230. P.447449 [in Russian].

Vorontsov N.N., Frisman L.V., Nadler C.F., Lyapunova E.A., Hoffman R.S., Fomicheva I.I. 1978. [Population genetics and genogeography of wild animals. I. Genogeography of transferrins and variants of glucose-6-phosphate-dehydrogenase in populations of Palaearctic longtailed ground squirrels Citellus (=Spermophilis) undulates] // Russian Journal of Genetics. Vol.14. P.805-816 [in Russian with English summary].

Yeh F.C., Boyle T.J.B. 1997. Population genetic analysis of co-dominant and dominant markers and quantitative traits // Belgian Journal of Botany. Vol.129. P.159.

Zheng S., Cai B. 1991. Fossil micromammals from the Donggou section of Dongyaozitou, Yuxian County, Hebei Province // Contribution to INQUA XIII. P.100-131.

Zhang Y.S., Jin G., Quan S., Li Z., Ye F., Wang Zhang M. 1997. Distribution of Mammalian Species in China. Beijing: China Forestry Publishing House. 394 p. 
Zheng Sh. 1994. Classification and evolution of the Siphneidae // Tomida Y.C. \& Setoguchi Li T. (eds.). Rodent and Lagomorph Families of Asian Origins and Diversification. National Science Museum Monographs, No.8. Tokyo: National Science Museum. P.57-76.
Zhou C., Zhou K. 2008. The validity of different zokor species and the genus Eospalax inferred from mitochondrial gene sequences // Integrative Zoology. Vol.3. No.4. P.290-298. 